\title{
Comparison of seismic analysis methods applied to a historical church struck by 2009 L'Aquila earthquake
}

\begin{abstract}
Yohei Endo ${ }^{1}$, Luca Pelà ${ }^{1 *}$, Pere Roca ${ }^{1}$, Francesca da Porto ${ }^{2}$, Claudio Modena ${ }^{2}$
This paper presents the seismic assessment of a historical church by means of different analysis methods. The church of San Marco, seriously damaged by 2009 L'Aquila earthquake, Italy, is chosen as case-study. The analysis tools adopted and compared are linear and non-linear kinematic analysis, FEM pushover analysis and FEM nonlinear dynamic analysis. The different methods are evaluated regarding their ability to predict the damage and collapse mechanisms actually caused by the earthquake. The accelerograms of the main shock of the $6^{\text {th }}$ April 2009 L'Aquila earthquake are considered for nonlinear dynamic analysis. The influence of relevant construction features, as original disconnection between parts or RC additions, is analysed into detail. Limit analysis is carried out to understand some of the critical collapse mechanisms which are not clearly revealed by FE analysis. The comparison of the analysis methods indicates advantages and limitations of each approach.
\end{abstract}

KEY WORDS: masonry, pushover analysis, nonlinear dynamic analysis, limit analysis, damage assessment, collapse mechanism.

\section{INTRODUCTION}

In spite of the effort devoted to the proposal and improvement of methods for the seismic assessment of masonry structures, the analysis of the seismic performance of historical buildings is still encountering significant difficulties. In part, such difficulties stem from the limited knowledge normally available on the history of the building, the historical alterations, the materials and the existing damage. However, an accurate seismic assessment of historical structures is of critical importance for the preservation of the architectural heritage.

Many historical masonry churches show significant vulnerability due to lack of horizontal stiffening diaphragms and limited material strength, especially in tension. Consequently, most of the collapse mechanisms under seismic actions derive from local out-of-plane behaviour (Giuffrè 1993). Typical collapse mechanisms of churches were categorised by the Italian Ministry for Cultural Heritage and Activities (2011) for macro elements such as façade, nave, triumphal arch, apse, dome and bell tower. A comprehensive web-based catalogue of collapse mechanisms of historical masonry buildings has been recently presented for different structural typologies (NIKER catalogue, 2013). As for the 2009 L'Aquila earthquake, extensive reports on collapse mechanisms and damage on historical structures have been presented, both for residential buildings (D'Ayala et al. 2011) and churches (da Porto et al. 2012, Lagomarsino 2012). In the latter case, it has been reported that the collapse

\footnotetext{
*Corresponding author luca.pela@upc.edu,+34 934011036

${ }^{1}$ DEC Department, Technical University of Catalonia (UPC-BarcelonaTech), Jordi Girona 1-3, 08034 Barcelona, Spain.

${ }^{2}$ DICEA Department, University of Padova, Via Marzolo 9, 35131 Padova, Italy.

E-mail addresses: yohei.endo@estudiant.upc.edu , luca.pela@upc.edu , pere.roca.fabregat@upc.edu , francesca.daporto@unipd.it , claudio.modena@unipd.it
} 
mechanisms involving the façade are the most representative. Triumphal arches, domes and vaults are also vulnerable members. Many churches were strengthened with modern materials including reinforced concrete $(R C)$ and fibre reinforced polymers (FRP) in the last 50 years. The inadequate use of these materials has caused, in some cases, negative effects on the behaviour of churches due to increase of mass and stiffness, as pointed out by Modena et al. (2011).

Currently available strategies for the analysis of masonry structures comprise simplified methods based on structural macro-elements, limit analysis, discrete element method (DEM) and micro- or macro- modelling based on the finite element method (FEM) (Roca et al. 2010). Results from the different approaches have been calibrated, in some cases, by comparison with damage and collapse mechanisms observed in experiments or in real structures. Comparisons between shaking-table tests on laboratory-built models and numerical simulations have provided useful information (De Matteis et al. 2010, Lourenço et al. 2011) even if such a costly approach is limited to research purposes. As an alternative, when an earthquake hits historical structures, it is possible to compare numerical results with real damage and collapses.

Limit analysis is frequently used for safety analysis and for the design of strengthening. One of the advantages of this method is that it can be carried out without requiring excessive computational effort. However, it can only be used to examine the ultimate state condition, and the choices of mechanisms to be analysed depend on the practitioner's experience. The determination of the most vulnerable mechanisms may not be simple when a large variety of them is possible in the structure. In many cases, limit analysis predicts an ultimate capacity similar to that yielded by FEM pushover analysis (Casarin et al. 2008). Boscato et al. (2014) have presented a case where overturning of a façade is predicted better by limit analysis than by nonlinear dynamic analysis (NDA).

Recently, DEM has been used in engineering applications. DEM can ideally simulate structural behaviour of blocky structures such as systems composed of columns and arches. The analysis of large structures may encounter difficulties related with the size of the DEM elements (Lemos 2007). In principle, the element sizes should be equal to the real dimensions of the masonry units; however, this may be impractical for large structures. Therefore, a simplified modelling strategy is normally used, with the element sizes becoming larger than the real ones. In this case, additional judgment is required so as to adjust deformability of joints and blocks.

FEM analysis programs have shown a large development and application in the last decades. In accordance with the level of accuracy and simplicity required, different strategies can be adopted, including the micro-modelling and the macro-modelling approaches. Micro-modelling, describing the behaviour of units, mortar and the unitmortar interface, is used for the detailed analysis of masonry individual members. Macro-modelling, on the other hand, does not make any distinction among masonry constituents and is applicable to large structures (Roca et al. 2012, Roca et al. 2013, Pelà et al. 2013a).

Nonlinear static (pushover) analysis, normally based on macro-modelling, is one of the commonly used tools for seismic assessment (Pelà et al. 2009). Nevertheless, it has been reported that it may not simulate properly the out-of-plane behaviour of structures (Lourenço et al. 2011). The distribution pattern of the seismic equivalent load is an influential factor and it needs to be chosen carefully, according to the performance of 
the structure. Frequently used distribution patterns are those defined in proportion to the mass of the structure and to the first modal shape. According to Galasco et al. (2006), the former load distribution induces more extensive damage while the latter can cause more damage on higher parts of the structure.

Eurocode 8 (CEN 2004) suggests the adoption of the N2 method proposed by Fajfar (2000), which combines pushover analysis with the capacity spectrum approach. This method correlates the displacement capacity of the structure to the displacement demand of the expected earthquake. For symmetrical structures, good performance has been observed. Although attempts have been made for asymmetrical buildings, further research is still required for other typologies. For highly irregular structures, the Italian Ministry for Cultural Heritage and Activities (2011) suggests the use of adaptive pushover analysis, in which the force distribution pattern is updated at each load step. Adaptive procedures are still under research (Galasco et al. 2006). Lourenço et al. (2011) applied a method where the load distribution pattern proportional to the first modal shape is updated as a function of the existing damage.

Alternative approaches to pushover analysis are response spectrum analysis (Pelà et al. 2013b) and nonlinear dynamic analysis in the time-domain (NDA) (Pelà et al. 2013c, Lourenço et al. 2011). With a set of carefully chosen ground records, NDA offers accurate evaluation of structural seismic response. However, its practical use still encounters difficulties due to its complexity and high computer effort demand. NDA is suggested to be used when detailed vulnerable assessment is required. For analysis of complex buildings, partial models are frequently used, involving, for instance, a representative bay of a church (Roca et al. 2013).

A limited number of works presents discussions about the comparison between NDA and pushover analysis of masonry structures (Pelà et al. 2013b). In spite of the attention devoted to the two methods, there are very few studies (Lourenço et al. 2011, Boscato et al. 2012) where their performance is compared for structural typologies corresponding to existing masonry churches.

This paper presents a contribution to the seismic analysis of historical masonry churches. The chosen case study is San Marco church, located in the historical centre of L'Aquila, Italy. The structure was severly damaged by L'Aquila earthquake on $6^{\text {th }}$ April 2009. After having conducted the post-earthquake emergency phases for building protection, the structure is currently under restoration.

The main objective of the paper is the discussion of the capability of the available methods to represent the observed seismic performance of the building. Different analyses are made to simulate the current damage condition, crack patterns and partial collapse mechanisms.

The study of San Marco church has been carried out in a detailed manner, by following the procedures recommended for built cultural heritage (ICOMOS 2005, Italian Ministry for Cultural Heritage and Activities 2011, Italian Ministry of Infrastructure and Transport 2009).

Historical research and in-situ inspection have been carried out to identify the different construction phases of the building, the geometry, the materials, the quality of the connections between the different structural elements and the possible vulnerabilities. In particular, past interventions with $\mathrm{RC}$ have been studied to assess their influence on the deterioration of the behaviour of the church. Lack of efficient connections among members, particularly at the intersection of the perimeter wall with the buttresses, has 
been carefully analysed since it affects considerably the seismic response. This first stage of the research has been useful for the preparation of the structural models for the analyses.

The damage and the partial collapses induced by the earthquake have been carefully surveyed. The analysis of cracks has made it possible to evaluate the structural behaviour of the church during the earthquake and to identify the relevant collapse mechanisms. .

The results obtained through different methods for seismic analysis (kinematic limit analysis, pushover analysis, nonlinear time-history analysis) are compared to evaluate their ability to predict the real collapse mechanisms. Both pushover analysis and NDA have been carried out using a global FE model of the church. The accelerograms of the main shock of the 6th April 2009 L'Aquila earthquake are considered for NDA. Kinematic limit analysis is carried out on representative macro-elements of the church. The result of the different methods are compared into detail with the real evidence of damage and collapse caused by the 2009 L'Aquila earthquake on the church.

\section{DESCRIPTION OF THE BUILDING}

\subsection{History of the building}

Comprehensive information on the building has been presented by Magi (2009), Silva et al. $(2010,2011)$, and therefore only a short summary of the historical and structural features relevant for the present paper is included here.

San Marco church was one of the first churches built in L'Aquila in the latter half of the $13^{\text {th }}$ century. The building experienced different historical events and construction phases (Figure 1). Medieval trace is found in the tympanum of the south portal which was built in the $14^{\text {th }}$ century. The façade seems to have been built at the beginning of the $15^{\text {th }}$ century. The right side of the building dates back approximately to the $15^{\text {th }}$ century. After the earthquake in 1315, partial reconstruction was conducted. The lateral chapels were built in the $16^{\text {th }}$ century. On the left side there were some buildings that were demolished after the earthquake of 1703. At that time the wall of this side was rebuilt and the presbytery rearranged. In 1750 two bell towers were constructed together with the top part of the façade.

The building stands in a narrow rectangular area and lays on a stone foundation. The length of the church is $41.7 \mathrm{~m}$ and the width is $16.0 \mathrm{~m}$ (Figure 1). The roof height is $16.7 \mathrm{~m}$. The height of the two bell towers of the façade is $21.5 \mathrm{~m}$. The nave is sided by three chapels at each flank. These chapels were built after the nave construction, as shown in Figure $1 \mathrm{~d}$ (black parts indicate the $13^{\text {th }}$ century construction). As a result, the exterior perimeter walls were not connected properly to the perpendicular walls between the chapels. This problem led to a local partial collapse of the church after the 2009 earthquake, as it will be discussed in Section 3. The nave is covered by reed vaults that are supported on brick masonry arches (Figure 1d). The lateral chapels are shielded by brick vaults. The transept area is covered by a shallow dome supported on four brick arches. The apse is roofed with a semi-dome. The dimensions of the bricks used for arches, domes and vaults are $290 \times 150 \times 30 \mathrm{~mm}^{3}$.

The structure underwent various interventions since the late $20^{\text {th }}$ century. The main structural interventions were carried out in 1970, 2005 and 2007. The first one was rather intrusive. Two longitudinal $R C$ beams and two transversal $R C$ tympanums were constructed, encircling the dome (Figure 2a-b). They constitute a heavy RC box formed 
over the transept. The entire pre-existing timber roof was replaced with a new system with prefabricated RC beams, hollow flat bricks and steel ties (Figure 2b). In 2005 the old iron ties at the top part of the bell towers were replaced with new steel ties. In 2007 carbon FRP (CFRP) strips were glued to the intrados of the arches supporting the dome (Figure 2c).

\subsection{Collapse mechanisms and damage after the 2009 earthquake}

A strong earthquake hit L'Aquila early in the morning (3:32 AM, local time) on $6^{\text {th }}$ of April of 2009. The magnitude was $M_{W}=6.3\left(M_{S}=6.3\right.$ and $\left.M_{L}=6.2\right)$ in accordance with the Italian Institute of Geophysics and Volcanology. The epicentre was shallow $(9.5$ $\mathrm{km}$ ) and very close to the historic centre of L'Aquila (approximately $7 \mathrm{~km} \mathrm{SW}$ ). Indirli et al. (2013) have presented a detailed discussion on the characteristics of the earthquake and an overview of damage in buildings. The earthquake was characterised by pseudo-acceleration response spectra with high peaks in the range of low periods, in spite of not very high magnitude. This may have been one of the reasons why rigid structures were subjected to strong forces (Modena et al., 2011).

Figures 3a-b show the accelerograms recorded at the Spanish fort (station AQU), the closest to San Marco church. The orientations of accelerograms are EW and NS, corresponding to longitudinal $(X)$ and transversal $(Y)$ directions of the church. The information has been obtained from the website of ITACA (ITalian ACcelerometric Archive, 2013). The spectra of the two records are shown in Figure 3c. They are compared with those provided by the Italian standards for the site of L'Aquila and a type B foundation, making use of the program Spettri-NTC (Italian Board of Public Works, 2008). Since San Marco church is a historical religious building, $10 \%$ exceeding probability in 75 years should be assumed (712 years of return period). However, the elastic spectrum with $10 \%$ exceeding probability in 50 years (475 years of return period) fits better the spectrum obtained from the accelerograms of the main shock and hence it will be considered for the analyses of this study.

Today San Marco church is under restoration due to the critical state caused to it by the earthquake (Modena et al. 2010). The damage and cracks were surveyed after the earthquake by a careful in-situ inspection, as shown in Figure 4 (Magi 2009, Silva et al. 2010, 2011). Several types of collapse were identified. Out-of-plane mechanisms occurred in the main façade (Figure 5a), in the upper part of the main façade, in the chapel walls (Figure 5b), in the transept walls and in the apse. The transversal behaviour of the nave produced heavy damage at the base of the piers and in the chapels. In-plane mechanisms occurred in the façade with deep diagonal cracking across the window (Figure 5c), and also in perimeter, transept and apse walls. Collapses affected the arches and reed vaults over the nave, the triumphal arch, the arches that support the dome of the transept, the semi-dome over the apse (Figure $5 d$ ), the chapel vaults and the wall above them in the south side (Figure 5e). The separation caused by the earthquake made it apparent the existing detachment between the buttresses and the perimeter wall (Figure 5f). Severe damage was observed in the dome. The south nave wall partially collapsed together with its underneath arches and buttresses. The development of this critical mechanism is discussed in detail in Sections 3 and 5. Damage was also detected at the top of the south nave wall, in a region under the roof and next to the bell towers (Figure $5 \mathrm{~g}$ ). 
From a preliminary analysis of damage distribution, it emerges that partial collapses were greatly influenced by the lack of efficient connection between façade and nave walls, and among chapels and perimeter walls. This structural defect is a result of the construction history, as mentioned in Section 2.1. After the earthquake, it was also possible to understand that the past interventions with RC and CFRP did not improve or even worsened the seismic behaviour of the structure. The collapses of the roof and the semi-dome in the apse, and also of the dome and the underneath arches, seem to be affected in a certain measure by the RC box introduced in 1970 over the transept. These hypotheses are supported by the FE simulations discussed in Section 5. CFRP strips implemented on arches did not work during the earthquake due to premature delamination resulting from their application at the intrados of the curved members.

\section{KINEMATIC LIMIT ANALYSIS}

Limit analysis is one of the approaches that have been selected to study the seismic behaviour of the church. From the damage mapping of San Marco church presented in Section 2, it emerges that in many portions of the structure the collapse was due to the loss of equilibrium of parts behaving as rigid blocks. The vulnerability to local mechanisms is also incremented by the lack of efficient connections among elements, like perpendicular walls. Consequently, the structure can be ideally divided into macroelements with an almost independent structural behaviour. On the basis of these considerations, the kinematic approach of limit analysis is adopted as a possible method to assess the failure load corresponding to local mechanisms. The objective of this analysis is to identify, for each kinematic admissible mechanism, the activation coefficient $\alpha_{0}$, defined as a multiplier of the seismic acceleration normalised according to $g$ (Giuffrè 1993). Applying the principle of virtual work for each chosen mechanism, it is possible to estimate the seismic capacity in terms of maximum force (linear kinematic analysis, LKA) and ultimate displacement by evaluating finite shifts (nonlinear kinematic analysis, NKA) (Italian Ministry of Infrastructure and Transport 2009). The activation coefficient $\alpha_{0}$ that induces the loss of equilibrium is obtained by evaluating the rotations between the blocks due to the initiation of the kinematic mechanism. The seismic performance of the structure is analysed until the full collapse by increasing the displacement of a control point and applying the principle of virtual works to the corresponding configurations. The curve obtained through the incremental kinematic analysis can be transformed into the equivalent SDOF system capacity curve. A direct comparison between the displacement ultimate capacity and the displacement spectrum demand can be done.

To perform this analysis it is necessary to define the geometry, the material properties, the confidence factor and the seismic action. The geometry and the material properties of the different elements of the church were obtained from previous studies of the church of San Marco (Magi 2009, Silva et al. 2010, 2011). The calculation of the confidence factor, i.e. the safety coefficient taking into account the uncertainties about the properties of historical structures, was carried out as specified by the Italian Guidelines (Italian Ministry for Cultural Heritage and Activities 2011).

A detailed analysis of possible failure mechanisms has been carried out for San Marco church. For the present research, previous applications of kinematic analysis (Magi 2009, Silva et al. 2011, De Conti 2013) have been reviewed and complemented. 
Figure 6 presents the summary of failure mechanisms considered in kinematic limit analysis with the indication of the activation coefficient $\alpha_{0}$ The weakest mechanism is the one involving the partial overturning of the upper nave wall (Figure 6a), which is activated for a coefficient $\alpha_{0}=0.081$. Other mechanisms considered are those involving the overturning of the perimeter wall (Figure 6b), the failure of the lateral buttresses and arches (Figure 6c), the overturning of the entire nave wall (Figure 6d), the overturning of the façade (Figure 6e), the failure of the apse (Figure 6f), and the inplane failure of the façade (Figure $6 \mathrm{~g}$ ). The damage and collapses experienced by the real structure suggest that all these mechanisms were actually activated. In spite of their activation, some mechanisms were only partially developed. For instance, the activation of the partial overturning and entire overturning of the nave wall (Figure 6a and $6 \mathrm{~d}$ ) could be actually observed after the earthquake due to the formation of damage at the base of piers and chapel walls, induced by the transversal response of the nave. However, such collapse mechanisms were not fully developed, possibly because of an effective connection of the walls with the façade and transept, or because of the anticipation of other mechanisms with close activation factor.

The partial collapse of the nave wall (Figure 5e) may be also explained by the mechanism described in Figure $6 c$ and Figure 7. In this case, the mechanism involves the overturning of the buttresses and the collapse of the arches supported on them. The activation coefficient $\alpha_{0}=0.099$ has been calculated taking into account a complex mechanisms including the overturning of the buttresses and a sufficient number of hinges in the arches (Figure 7d). As a result of this mechanism, the upper nave wall losses it support on the arches and detaches vertically forming the actually observed relieving arch at its upper part (Figures $7 a-b$ ). This mechanism is made possible by the lack of connection between the perimeter wall and the buttresses due to the construction process, as discussed in Section 2 and shown in Figure 5f. The low activation coefficient obtained (0.099) shows the likelihood of this type of failure, which is consistent with the damage and collapses observed in the lateral façades of the church. However, the combined effect of the in-plane and transversal response of the nave wall cannot be disregarded in the interpretation of the collapse.

The overturning of the main façade is activated for $\alpha_{0}=0.167$ (Figure 6e). The façade has been supposed partially connected to the orthogonal walls, according to the morphology derived from historical and on-site inspection.

The out-of-plane overturning of the apse, assumed disconnected from the semi-dome area, corresponds to $0.217 \mathrm{~g}$. When the apse and the semi-dome overturn together (Figure 6f), the seismic coefficient is nearly the same $(0.218 \mathrm{~g})$.

The in-plane failure of the façade occurs for $\alpha_{0}=0.354$ (Figure $6 \mathrm{~g}$ ). Even though this mechanism is related to a rather high collapse coefficient, it has been actually activated as can be recognized from damage observed at both the interior and exterior paraments of the façade.

The occurrence of highly developed mechanisms and even collapse is investigated by considering the limit State of Life Safeguard (SLV) according to the Italian standards (Italian Ministry of Infrastructure and Transport 2009), using both LKA and NKA. In the application of LKA the spectral acceleration $a^{*}{ }_{0}$ of mechanism activation is compared with the demand acceleration divided by a structural factor $q$ taken equal to 2 . The spectral acceleration $a^{*}{ }_{0}$ is computed as $\alpha_{0}$ divided by the mass participation factor and 
the confidence factor FC. The mass participation factor is equal to 1 except for mechanisms c) and g), with values equal to 0.92 and 0.98 respectively. Since the aim of the study is the comparison with actually occurred mechanisms, the confidence factor is taken equal to the unit. The demand acceleration has been calculated according to the Italian standards (Italian Ministry of Infrastructure and Transport 2009). For the factor $q=2$, the reference demand acceleration to be considered in the comparison is equal to $0.15 \mathrm{~g}$.

All mechanisms interesting the lateral walls (Figures 6a-d), and specifically the mechanism involving the collapse of the chapel buttresses and arches (Figure 6c), are below this reference value. Conversely, the mechanisms associated to the in-plane failure of the façade and the overturning of the façade and apse show activating coefficients above the reference value, meaning that they should not be expected to attain a condition close to full collapse.

As a second step, the limit state of life safeguard (SLV) is assessed by NKA. Following the specifications of the Italian standards, and for the different mechanisms considered, the ultimate displacement capacity $d_{u}{ }^{*}$ is calculated for each mechanism and compared with the value of the displacement demand $\Delta_{d}$. The SLV condition is satisfied if $d_{u}{ }^{*} \geq \Delta_{d}$. The calculation of both terms has been carried out with the software c-Sisma (Modena et al. 2009).

Figure 6 compares the values of $d_{u}{ }^{*}$ and $\Delta_{d}$ for the different mechanisms. As can be seen in the figure, the SLV condition is not verified for mechanisms a) and c), respectively corresponding to the overturning of the upper part of nave wall and the collapse of the system of arches and buttresses of the chapels which, as mentioned before, may have been caused as well the vertical detachment of the upper part of nave wall. Both mechanisms show a similar ratio, of about 0.9 , between the ultimate displacement capacity and the displacement demand. The SLV condition is verified for the rest of the mechanisms, which helps explain why some of these mechanisms (specifically, mechanisms e) and g) corresponding to overturning and in-plane failure of the façade and mechanism $\mathrm{f}$ ), corresponding to the overturning of the apse) have been only partially activated by the earthquake. In the case of the set of mechanisms analysed, the comparison between LKA and NKA shows that the former produces more conservative results, having in all the cases yielded ratios between capacity and demand higher than the latter.

\section{FE MODEL FOR STRUCTURAL ANALYSIS}

A FE model of the entire church (Zografou 2010) has been prepared for nonlinear analyses, using the TNO DIANA software (2005). The aim of the study is to identify and simulate the mechanisms that led to the damaged condition of the church. The model represents the state of the structure just before the 2009 earthquake. The RC members of the 1970 intervention, i.e. tympanums and beams over the transept, are included in the model. The disconnection among the buttresses supporting the chapel vaults and the external walls is properly modelled, since it is very influential on the global behaviour. Disconnection among finite elements is realised by duplicating nodes at the connections. Interface elements are not considered in order to reduce the computational cost. Since falling of roof trusses occurred during the earthquake of 2009 , the roof beams are not discretised to avoid overestimation of the stiffening effect given by the flexible roof. However, their masses are lumped to the top edge of walls. 
Silva et al. (2010) estimated the mechanical properties of masonry through inspection, according to the Italian standards (Italian Ministry of Infrastructure and Transport 2009). The façade is composed of dressed rectangular (ashlar) non-soft stone masonry and the north nave wall of uncut stone masonry, of variable dimensions, with prevailingly horizontal layers. The material properties that have been assumed in the analysis are listed in Table 1. Nonlinear properties are assigned to both masonry and RC. A smeared cracking model with a Rankine failure criterion for tension and a plasticity model with Drucker-Prager failure criterion for compression are adopted. Timber members are modelled as linear elastic. The model is composed of 14217 quadrilateral four-node shell elements, 1333 triangular three-node shell elements (both shell elements possess 11 integration points in thickness), 205 straight two-node 3D beam elements and 115 one-node translational mass elements to provide the dead load over the roof beams (Figure 8). The total number of nodes is 16976 . The RC beams and tympanums in the transept are modelled with four-node quadrilateral and three-node triangular shell elements. Given the symmetry of the structure, half of the model is employed for the analysis in the longitudinal direction with appropriate boundary conditions. Both geometrical and mechanical nonlinearities are considered in the analyses.

\section{NONLINEAR STATIC ANALYSIS}

Pushover analysis of the church is carried out in three directions: positive longitudinal $(+X)$, negative longitudinal $(-X)$ and transversal $(Y)$. Gravity is applied in a first loading step and then seismic forces proportional to mass of the structure are incremented until the analysis stops due to the collapse of the model. The capacity curves have been defined making reference to different control points, shown in Figure 8, in order to follow the response of the most critical parts of the structure during the analysis (Pelà et al. 2009, 2013c).

\subsection{Longitudinal direction}

In the positive longitudinal direction $(+X)$, the first horizontal branch of the capacity curve is seen at an acceleration of $0.085 \mathrm{~g}$ (Figure 9a). At this point, separation of the façade from the nave and cracking in the chapel vault close to the transept starts. Damage in the arch between the nave and the transept starts to appear as well. This damage keeps developing until the ultimate condition is reached. A diagonal crack across the arch in the transept and the dome starts to appear also at this stage. The ultimate state is reached for an acceleration of $0.165 \mathrm{~g}$ and a displacement at the top of the bell tower of $43 \mathrm{~mm}$. The failure is due to the overturning of the façade with part of the chapel wall, leading in turn to the detachment of the nave wall from the transept (Figures 9b-c).

The capacity resulting from this analysis agrees well with the activation coefficient obtained for the façade overturning mechanism by LKA $(0.165 \mathrm{~g}$ vs. $0.167 \mathrm{~g})$. This fact may indicate that both approaches are able to represent correctly this type of failure. In the real building, the activation of the out-of-plane mechanism of the façade was recognisable from both the inside and the outside (Figures 10a-b) and an urgent intervention was required for its stabilisation (Figure 10c). Damage in the arch and in the dome was also observed in the real structure. However, the partial collapse of the 
upper part of the south nave wall is not completely represented by the FE model. The buttresses supporting the chapel vaults are significantly deformed due to the disconnection from the perimeter wall. This problem induces the formation of damage in the vault of one of the lateral chapels, as shown in Figure 9c, starting at the acceleration of $0.105 \mathrm{~g}$. However, the FE analysis does not afford the simulation of the loss of balance of the vaults and the consequent falling of the wall above. In spite of it, the threshold of damage formation in the structure is in a good agreement with the seismic coefficient $\alpha_{0}=0.099$ derived from limit analysis for out-of-plane overturning of buttresses.

In the negative longitudinal direction (-X) damage starts to appear in the connection between the facade and the nave and also on the vault of the chapel next to the façade for an acceleration of $0.09 \mathrm{~g}$ (Figure 11a). At $0.111 \mathrm{~g}$, damage appears also in the vault of one of the chapels. This value is close to that observed in the positive longitudinal direction. At $0.19 \mathrm{~g}$, the capacity curve shows a first horizontal branch, corresponding to damage arising in the perimeter wall. When the curve reaches the second horizontal branch $(0.217 \mathrm{~g})$, the out-of-plane movement of the apse becomes visible and a diagonal crack across the window in the transept wall also appears (Figures 11b-c). The ultimate acceleration is $0.217 \mathrm{~g}$ and the corresponding displacement is $19 \mathrm{~mm}$ at the top of the apse wall. The failure is due to the out-of-plane behaviour of the apse, leading, in turn, to the failure of a chapel vault and the in-plane failure of the transept and perimeter walls. High concentration of damage is seen in the connection between the façade and the nave, and between the nave and the transept. Most of the failures predicted by $-X$ pushover analysis, including the out-of-plane behaviour of the apse, were also observed in the real structure (Figure 12). The ultimate acceleration of FEM analysis is close to the activation coefficient $\alpha_{0}=0.218$ derived from LKA for out-ofplane overturning of the apse wall.

\subsection{Transversal direction}

The main prediction of pushover analysis in the transversal direction is found in the global overturning of the nave wall (Figure 13). At the acceleration of $0.045 \mathrm{~g}$ some damage appears in the chapel vault and in the connection between the nave walls and the façade, and between the transept and the nave walls. At $0.08 \mathrm{~g}$, damage in the arch of the transept starts to appear. The out-of-plane deformation is more noticeable in the south wall than in the north one (Figure 13a). This asymmetrical behaviour may be due to geometrical nonlinearity. In fact, an additional FE analysis without geometrical nonlinearity showed nearly equal ultimate displacements of both walls. Another factor to be considered for this difference is the disconnection among buttresses and chapel walls.

At the acceleration of $0.12 \mathrm{~g}$, the damage concentrates in the middle part of the bent nave wall, and then at $0.125 \mathrm{~g}$ diagonal cracks arise from the middle part of the nave wall and propagate by involving the windows. Finally, the analysis stops when the whole nave wall overturns at the ultimate state $(0.1254 \mathrm{~g})$. This value is similar to the activation coefficient obtained for the nave wall overturning in LKA (0.116).

The complete overturning of the entire nave wall was not observed after the earthquake even if its activation could be somehow visible, as already discussed in Sections 2.2 and 3. As also reported in Sections 3 and 5.1, the partial downfall of the upper nave wall may have been caused also by the combined collapse of the lateral 
arches and buttresses under longitudinal loading (Figure 6c). It is believed that pushover analysis in the transversal direction does not provide such failures but only the global overturning mechanism. It is possible that transversal seismic excitation had contributed to collapse of the upper part of the south nave wall.

At the ultimate state, significant damage can also be observed in the FE model in the arches of the transept (Figures 13b-c). In particular, the arch between the nave and the transept is seriously damaged. High damage concentration is also seen at the end of the RC tympani. The bottom of the buttresses is also damaged due to the out-of-plane behaviour of the entire nave wall (Figure 13c). All the aforementioned failures were also detected in the structure after the earthquake (Figure 14). In turn, in-plane failure of the façade is not predicted although it was observed after the earthquake.

\section{NONLINEAR DYNAMIC ANALYSIS}

The nonlinear dynamic analysis (NDA) is carried out with the accelerograms shown in Figures 3a-b. The FE model and its material properties are the same that have been used for pushover analysis. A Rayleigh damping model is considered, with massproportional and stiffness-proportional damping coefficients respectively equal to $a_{0}=0.5789$ and $a_{1}=0.0042$. The Newmark-beta method has been used for the integration in the time domain. Constant average acceleration is assumed within each time step, with parameters $\gamma=0.5$ and $\beta=0.25$. Time intervals of 0.002 seconds have been assumed. Sensitivity analyses have been carried out to assess the accuracy of the adopted time discretization. The duration of the input ground motion in each NDA depends on the considered earthquake record, with 12 seconds assumed.

The N2 method (Fajfar 2000) is adopted to compare the results obtained from the pushover analysis and those from NDA in terms of the seismic performance estimations. The capacity curves are bi-linearised by following the energy balance principle, i.e. equating the areas between the bilinear and the capacity curve. The seismic demand is determined by the intersection point between the bilinear capacity curve and the inelastic response spectrum.

\subsection{Longitudinal direction}

The NDA along the longitudinal direction (X) stops after 2.74 seconds (Figures 15a-b). Significant increase of the acceleration is seen after 2 seconds, according to the shape of the accelerogram. The maximum displacement of the structure $(31 \mathrm{~mm}$ at the top of the bell tower) occurs at 2.6 seconds. At this moment, the principal tensile strain contours indicate the detachment of the façade. Damage can be seen under the roof in the right part of the south façade, near the connection with the tower, as actually observed after the earthquake (Figure $5 \mathrm{~g}$ ). Damage can be found also in the arch of the transept, in the upper part of the south nave wall and the chapel vault adjacent to the transept (Figures 15c-d), in good agreement with the real collapse. Although some damage is found at the connection between the presbytery and transept, no activation of the out of plane failure of the apse is observed.

Outcomes of NDA are compared with those of the pushover analysis by N2 method. The displacement (top of the bell tower) at the performance point is $26 \mathrm{~mm}$ and the acceleration is $0.14 \mathrm{~g}$ (Figure 16a). In turn, the maximum displacement obtained in NDA is $31 \mathrm{~mm}$ and the corresponding acceleration is $0.09 \mathrm{~g}$. The two analyses provide 
very similar estimations of the displacement due to earthquake. When the contours of principal tensile strains at the performance point of pushover analysis (Figure 16b) are compared with those for the maximum displacement of NDA (Figures 15c-d), they both illustrate similar patterns of damage. However, in the NDA the principal tensile strains present smaller magnitude and are more distributed in walls and less concentrated in the connections. Pushover analysis describes a more critical state than NDA regarding the overturning of the façade, the shear mechanism in the wall of the lateral chapel, the damage around the window in the south nave wall and the separation of the nave wall from the transept (Figure 16b).

\subsection{Transversal direction}

The NDA along the transversal direction (Y) stops after 2.21 seconds (Figures 17a-b). Significant increase of the acceleration is seen before 2 seconds, leading to ultimate state. The maximum displacement of $102 \mathrm{~mm}$ is observed at the top of the north nave wall at the ultimate state. The contour of principal tensile strains at the ultimate state (Figures 17c-d-e) indicates the overturning of both north and south nave walls, whereas concentration of damage is seen in the arches of the transept. The arch between the nave and the transept is significantly damaged.

From the comparison between the time-histories of the nave walls it emerges that although the south wall shows the maximum positive displacement, the maximum negative displacement is observed in the north wall. The movement towards the nave results larger than the outward deformation. This is due to the effect of the buttresses and the influence of the geometrical nonlinearity, as discussed in Section 5.2.

Outcomes of NDA are compared again with those of the pushover analysis by N2 method. The displacement at the top of the nave wall at the performance point is 69 $\mathrm{mm}$ and the corresponding acceleration is $0.125 \mathrm{~g}$. This displacement is lower than that from NDA $(87.5 \mathrm{~mm})$ (Figure 18a). The maximum acceleration predicted by NDA $(0.245 \mathrm{~g})$ is also higher. Principal tensile strain values at the performance point are more moderate in NDA than in pushover analysis. Damage appears more distributed in NDA than in pushover analysis, especially in the transept area (Figures 18b-c).

\section{DISCUSSION}

\subsection{Prediction of real damage and collapse}

The comparison of the results by the different methods shows their performance and ability to predict the actually observed damage and collapse mechanisms.

In fact, all the methods tested (limit analysis, FEM pushover analysis and NDA) have been able to predict most of the observed damage and collapse for a seismic demand similar to that caused by the real earthquake of 2009. The comparison among different methods has contributed to the understanding of the real performance of the structure and the collapse mechanisms actually activated. All methods satisfactorily predict, for a similar demand level, the overturning of the façade, the separation of the nave wall from the transept, the collapses of the chapel vaults, and the failure of arches of the transept, of the dome and the apse. FEM pushover and limit analysis have estimated similar maximum accelerations for most of the collapse mechanisms analysed, as in particular for the chapel vaults and nave wall $(0.105 \mathrm{~g}$ vs. $0.099 \mathrm{~g})$, the façade 
overturning ( $0.165 \mathrm{~g}$ vs. $0.167 \mathrm{~g})$, overturning of the entire nave wall $(0.125 \mathrm{~g}$ vs. 0.116 $\mathrm{g}$ ) and the apse wall overturn ( $0.217 \mathrm{~g}$ vs. $0.218 \mathrm{~g})$.

However, some of the collapses observed after the earthquake, as in particular that of the upper part of the south nave wall, have been only indirectly inferred from the outcome of these methods. In this particular case, all methods predict the failure of the chapel vaults on which the mentioned wall is supported. The failure of the wall can be understood, in all cases, as a logical consequence of the collapse of its supporting elements (the vaults). This understanding is consistent with the generation of the relieving arch at the upper part of the wall that can be recognised in the damaged structure (Figure 7a). Nevertheless, the numerical methods utilised do not afford the simulation of the collapse of the wall itself because the structure already reaches an ultimate condition at the failure of the arches, causing the analysis to stop at this point. A detailed simulation of the collapse of the wall would require a more sophisticated approach (such as DEM) overcoming the limitations of continuous mechanics in the description of realistic masonry collapsing mechanisms.

Limit analysis predicts the possibility of a full overturning of the whole nave wall which, in fact, was only activated and partially developed. Also in this case, the failure of the upper portion of the nave wall (below the reliving arch) can be understood as a consequence of the failure of the supporting arches, which happens, according to this analysis, for a lower activation coefficient $(0.099 \mathrm{~g}$ for the chapel vaults collapse against $0.116 \mathrm{~g}$ for the entire nave wall overturning). In the real structure, the whole nave wall overturning seems to have been prevented by the connections with the façade and transept walls. Hence, it should be noted that the decomposition of the structure into fully disconnected macroelements may in some cases lead to predict mechanisms not fully developed in the structure. In addition, it is difficult to combine the perpendicular horizontal components of the seismic action in the limit analysis of macroelements.

Comparison between pushover predictions through N2 method and NDA yields also some meaningful conclusions. Although pushover analysis represents similar damage distributions, compared to NDA, for both longitudinal and transverse earthquakes, NDA causes a more distributed damage pattern which, in some places, is more in agreement with the cracking observed in the real structure. Some of the mechanisms, such as those involving the collapse of the chapel vaults, the nave wall and the arches of the transept are better represented by NDA than by pushover analysis.

The maximum displacement values provided by NDA are close to the ones yielded by pushover analysis at the performance point by $\mathrm{N} 2$ method for the façade overturning (31 $\mathrm{mm}$ for NDA and $26 \mathrm{~mm}$ for pushover). However, a significant discrepancy has been obtained for the displacements associated to the nave wall collapse which, as mentioned, is in fact a mechanism not adequately simulated by these methods.

\subsection{Influence of wall-wall connections}

In spite of the agreement obtained between the pushover and the limit analysis results, in general, limit analysis shows to be more conservative. This fact can be understood as a consequence of the decomposition of the structure into fully disconnected macroelements, while for the FEM approaches the analysis have been carried out on global models with assumed initially intact connections. The comparison with the real damage and collapse mechanisms suggests that the real situation may be an 
intermediate one between those described by the macroelements and the global models. In reality, the connections of the structure (as in particular those between the different perpendicular walls) may have been showing some degree of imperfection due to construction defects or initial cracking and deterioration. The results of the FEM analysis might be improved by artificially weakening these connections in the models. However, this possibility brings out the need for a detailed characterisation and accurate mechanical modelling of the imperfect connections, which in practice are hardly attainable in an objective way. Actually, some additional analysis were carried out with initially weakened connections, and it was obtained, as expected, that the results tended to become more similar to the limit analysis' ones.

In any case, the above considerations highlight the need for a previous detailed inspection and recognition of the construction features and condition of the connections. Specifically, lack of connection (or weak connection) linked to architectural alterations or different construction phases should be carefully assessed. In the case of San Marco, one of the aspects having largely influenced on the simulated response of the building is found in the disconnection between the buttresses and the perimeter north and south walls (as already presented in Section 2.1). It has been observed that neglecting this construction feature leads to largely unsafe results. As should be expected, FEM analyses on a model with perfect buttresswall connection produce more optimistic results on the seismic response of the building. For instance, $+X$ direction pushover analysis of the model with perfect connection provides a load capacity of $0.193 \mathrm{~g}$ that is higher than that obtained by the model with disconnections $(0.165 \mathrm{~g})$.

Nonlinear geometric effects have been found significant for the study of the earthquake in the transverse direction. This influence is due to the deformation of the nave walls with respect to the buttresses on which they are supported. According to the pushover analysis performed, considering geometric nonlinearity caused a reduction of $15 \%$ on the displacement capacity in the transverse direction, while it did not sensibly affect the load capacity. Therefore, and even if the structure does not show significantly slender members, considering geometric nonlinear analysis seems advisable in the seismic assessment of similar structures.

\subsection{Influence of RC additions}

Some additional FE analyses have been carried out on a model representing the structure before the intervention carried out in 1970, i.e. without the RC tympanums and beams in the transept and with lighter timber joists instead of the concrete ones in the roof. Pushover and NDA have been carried out in both longitudinal and transversal directions.

As for pushover analyses, the FE model before the 1970 intervention (1970 model) provides always a lower elastic stiffness and a higher capacity than the model of the structure after the intervention (2009 model). The maximum accelerations obtained are $0.169 \mathrm{~g}$ vs. $0.165 \mathrm{~g}$ for $+X$ direction; $0.229 \mathrm{~g}$ vs. $0.217 \mathrm{~g}$ for the $-X$ direction; $0.141 \mathrm{~g}$ vs. $0.125 \mathrm{~g}$ for the $\mathrm{Y}$ direction). Also the displacement capacity results similar or higher for the 1970 model than in the 2009 one (+X direction at the centre of the arch between the nave and transept: $30 \mathrm{~mm}$ vs. $31 \mathrm{~mm}$; $-X$ direction at the top of the apse wall: 21 $\mathrm{mm}$ vs. $19 \mathrm{~mm}$; $Y$ direction at the top of the transept wall: $28 \mathrm{~mm}$ vs. $23 \mathrm{~mm}$ ). The 
collapse mechanisms are similar for both models, but the 1970 model is more damaged in the transept area than the 2009 model (see Figure 19).

As for NDA, the 1970 and 2009 models stop at a similar instant (X direction: $2.72 \mathrm{~s}$ vs. $2.74 \mathrm{~s}$; $Y$ direction: $2.38 \mathrm{~s}$ vs. $2.21 \mathrm{~s}$ ). The maximum displacement also results larger in 1970 model than in the 2009 one (X direction at the centre of the arch between the nave and transept: $20 \mathrm{~mm}$ vs. $18 \mathrm{~mm}$; $Y$ direction at the top of the transept wall: $32 \mathrm{~mm}$ vs. $25 \mathrm{~mm}$ ). NDA displays concentration of damage in the transept area, as also observed the pushover analysis (Figure 21). In summary, both pushover and NDA predict a better seismic performance before the interventions carried out in 1970. The negative effect of the strengthening with RC members is clearly represented by both approaches. The 1970 restoration worsened the seismic structural behaviour, since heavy masses were added at the level of the roof, increasing the inertial forces due to earthquake, and rigid elements were added to the structure, leading to an irregular distribution of the stiffness and forces. .

Pushover analysis and NDA have been also carried out on a model representing the structure in 2009 but with linear elastic RC members instead of inelastic ones. Pushover analyses have shown higher capacity in this case than in the reference model with nonlinear RC. For instance, in the pushover analysis along the positive longitudinal direction, the maximum acceleration and displacement result $0.169 \mathrm{~g}$ and $44 \mathrm{~mm}$ (at the control node of the arch), whereas in the reference model they were $0.165 \mathrm{~g}$ and $21 \mathrm{~mm}$. As for NDA, the analysis lasts longer than in the reference model. Therefore, the properties of the RC members need to be determined carefully in nonlinear seismic analysis since the assumption of linear elastic properties may lead to an overestimation of the seismic capacity.

\section{CONCLUSIONS}

A seismic assessment by different analysis methods of an historical church struck by 2009 L'Aquila earthquake has been presented. The real damage and the collapse mechanisms produced by the earthquake have been directly compared with the mechanisms derived from the structural analysis. Three different methods have been considered and compared: nonlinear static (pushover) analysis, nonlinear dynamic analysis (NDA) and limit analysis. FE analysis combined with the limit analysis has been shown, with some limitations, as a suitable approach for the study of a typical church structure (a building without box-behaviour). However, FEM analysis must be applied on a realistic model of the structure adequately taking into account the nonlinear material properties, the construction features and the real connection between the different parts. In the case of San Marco church, modelling the existing lack of connection between certain parts (buttresses and perimeter walls), built at different construction phases, has been important to attain an adequate simulation of the real collapse mechanisms. An adequate modelling of the alterations and the RC additions of 1970 has been also necessary to realistically simulate their influence on the structure's performance. All this highlights the importance of historical research and in-situ inspection for this type of studies.

Pushover analysis and NDA have afforded the simulation of the major real collapse mechanisms activated in the structure. These include the overturning of the façade, the collapse of the dome, the failure of the arches of the transept and the partial collapse of the nave wall. The simulation of the latter has required the modelling of the 
disconnection between the external walls and the buttresses in the chapel. It must be noted, however, that the numerical approaches have failed to predict some of the mechanisms actually activated by the earthquake, such as the in-plane mechanism of the façade. A specific limitation of the methods utilised has been found in the numerical simulation of mechanisms involving the loss of balance of walls set over collapsing arches. Such types of failures are difficult to simulate in continuum mechanics FE models and may require alternative approaches such as the DEM.

In FEM-based nonlinear seismic analyses of complex buildings, it is important to choose different control nodes and to compare their capacity curves in order to identify which are the most vulnerable elements and to understand the sequence of local failures during the earthquake.

In spite of the observed limitations, pushover analysis on a model of the entire structure has revealed to be a practical tool for seismic assessment of a historical church. This approach seems a good compromise between limited computational cost and accuracy of results. However, the interpretation of pushover analysis results may pose some difficulties. For this reason, it is advisable to combine distinct analysis methods in order to cover the limitations of each one.

As for the ultimate capacity, pushover and limit analysis have shown good agreement for some mechanisms. In the present study, NDA has produced a higher value of maximum acceleration than pushover analysis for earthquakes acting either in the longitudinal or transverse direction.

The N2 method has been used to compare NDA and pushover analysis results in terms of structural capacity and seismic performance. It is worth noting that N2 approach still requires further investigation for the case of irregular structures.

Although this paper considers a single case-study, it is believed that the outcomes of this research may be of interest for further seismic assessments of historical churches.

\section{ACKNOWLEDGMENTS}

The studies presented here have been developed within the Project NIKER (New Integrated Knowledge based approach to the protection of cultural heritage from Earthquake-induced Risk), Contract Agreement 244123, funded by the 7th Frame Programme of the European Union, whose assistance is gratefully acknowledged. This research has also received the financial support from the Ministerio de Educación y Ciencia of the Spanish Government and the ERDF (European Regional Development Fund) through the research project MICROPAR (Identification of mechanical and strength parameter of structural masonry by experimental methods and numerical micro-modelling, ref num. BIA2012-32234).

\section{FIGURE CAPTIONS}

Figure 1 - San Marco church: (a-b-c) façade, north and south side, (d) plan.

Figure 2 - Past interventions visible after the earthquake: (a) location of RC beams and tympanums, (b) RC tympanum over the transept and new roof and (c) CFRP strips installed on the intrados of arches. 
Figure 3 - Accelerograms of L'Aquila main shock in the EW direction (a) and NS direction (b), comparison of corresponding spectra with those provided by Italian standards for the city of L'Aquila for different return periods (c).

Figure 4 - Maps of crack patterns observed after the earthquake: (a) façade, (b) apse, (c-d) nave and chapels and (e) top view.

Figure 5 - Some mechanisms observed after the earthquake: (a) overturning of façade and (b) lateral chapel walls, (c) shear mechanism in the façade, (d) collapse of the semi-dome and the roof in the apse, (e) collapse of the lateral chapel and the wall above, (f) disconnection between the chapel wall and external wall and $(\mathrm{g})$ damage under the roof in the south nave wall.

Figure 6 - Collapse mechanisms and corresponding coefficients obtained by limit analysis.

Figure 7 - Collapse of the chapels and upper part of the south nave wall (De Conti 2013): (a) outside and (b) inside views, (c) identification of the macroelement and (d) kinematic analysis of the mechanism.

Figure 8 - Global FE model of San Marco church and location of control nodes for nonlinear seismic analyses.

Figure 9 - Pushover analysis in the positive longitudinal direction (+X): (a) capacity curves at different control nodes and $(b-c)$ contour of principal tensile strain at the ultimate state.

Figure 10 - Real collapse mechanism detected by $+X$ direction pushover analysis: (a) overturning of the façade seen from the exterior and (b) from the interior, (c) postearthquake urgent intervention by ties and timber propping.

Figure 11 - Pushover analysis in the negative longitudinal direction (-X): (a) capacity curves at different control nodes and $(b-c)$ contour of principal tensile strain at the ultimate state.

Figure 12 - Collapse mechanisms detected by -X direction pushover analysis: (a-b) out-of-plane overturning of the apse and (c-d) separation of the transept wall from the arch sustaining the dome.

Figure 13 - Pushover analysis in the transversal direction (Y): (a) capacity curves at different control nodes and $(b-c)$ contour of principal tensile strain at the ultimate state.

Figure 14 - Collapse mechanisms detected by $Y$ direction pushover analysis: (a) arches in the nave, (b-c) walls and buttresses in lateral chapels, d) transept arches.

Figure 15 - NDA in the longitudinal direction $(X)$ : (a) time-history of displacements at different control nodes, (b) comparison accelerogram vs. acceleration at the base of the structure and (c-d) contour of principal tensile strain at $2.6 \mathrm{sec}$.

Figure 16 - Comparison between NDA and N2 method, longitudinal direction (X), top of the façade control node: (a) NDA acceleration-displacement envelope compared with the capacity curve and (b) contour of principal tensile strains at the performance point of pushover analysis.

Figure 17 - NDA in the transversal direction (Y): (a) time-history of displacements at different control nodes (b) comparison accelerogram vs. acceleration at the base of the structure and (c-e) contour of principal tensile strain at $2.21 \mathrm{sec}$.

Figure 18 - Comparison between NDA and N2 method, transversal direction (Y), top of the nave wall control node: (a) NDA acceleration-displacement envelope compared 
with the capacity curve and (b-c) contour of principal tensile strain at the performance point of pushover analysis.

Figure 19 - Pushover analysis of the model of the church before the interventions with $\mathrm{RC}$ members of 1970: contour of the principal tensile strain at the ultimate state for (a) positive longitudinal direction $(+X)$, (b) negative longitudinal direction $(-X)$ and (c) transversal direction $(\mathrm{Y})$.

Figure 20 - NDA of the model of the church before the interventions with RC members of 1970. Contour of the principal tensile strain at the maximum displacement: (a) longitudinal direction (2.6 seconds) and (b) transversal direction (2.37 seconds).

\section{TABLES CAPTIONS}

Table 1 - Mechanical properties for FEM analysis.

\section{REFERENCES}

- Boscato G, Pizzolato M, Russo S, Tralli A (2014) Seismic Behaviour of a Complex Historical Church in L'Aquila Int J Archit Herit 8(5):718-757

- Casarin F, Modena C (2008) Seismic Assessment of Complex Historical Buildings: Application to Reggio Emilia Cathedral, Italy. Int J Archit Herit 2:304-327

- CEN (2004) Eurocode 8: Design Provisions for Earthquake Resistance of Structures, Part 1.1: General rules, seismic actions and rules for buildings. European Committee for Standardisation, Brussels

- Da Porto F, Silva B, Costa C, Modena C (2012) Macro-scale analysis of damage to churches after earthquake in Abruzzo (Italy) on April 6, 2009. J Earthq Eng 16(6):739758

- D'Ayala DF, Paganoni S (2011) Assessment and analysis of damage in L'Aquila historic city centre after 6th April 2009. B Earthq Eng 9(1):81-104

- De Conti A (2013) Seismic analysis and simulation of collapse mechanism of a masonry church. Dissertation, Technical University of Catalonia, University of Padova.

- De Matteis G, Mazzolani FM (2010) The Fossanova Church: Seismic Vulnerability Assessment by Numeric and Physical Testing. Int J Archit Herit 4:222-245

- Fajfar P (2000) A nonlinear analysis method for performance based seismic design. Earthq Spectra 16(3):573-592

- Galasco A, Lagomarsino S, Penna A (2006) On the use of pushover analysis for existing masonry buildings. Proceedings of the First European Conference on Earthquake Engineering and Seismology. Geneva, Switzerland, Paper n. 1080

- Giuffrè A (1993) Sicurezza e conservazione dei centri storici. II caso Ortigia (in Italian). Laterza: Bari

- ICOMOS/ISCARSAH Committee (2005) Recommendations for the analysis, conservation and structural restoration of architectural heritage. http://www.icomos.org/en/ Accessed 27 June 2013

- Indirli MS, Kouris LA, Formisano A, Borg RP, Mazzolani FM (2013) Seismic Damage Assessment of Unreinforced Masonry Structures After The Abruzzo 2009 Earthquake: The Case Study of the Historical Centers of L'Aquila and Castelvecchio Subequo. Int J Archit Herit 7:536-578

- ITACA, ITalian ACcelerometric Archive (2013) http://itaca.mi.ingv.it/ltacaNet/ Accessed 27 June 2013

- Italian Board of Public works (2008) Spettri-NTC ver 1.03. www.cslp.it Accessed 27 June 2013 
- Italian Ministry of Infrastructure and Transport (2009) Circolare 2 febbraio 2009, n. 617 - Istruzioni per l'applicazione delle «Nuove norme tecniche per le costruzioni» di cui al decreto ministeriale 14 gennaio 2008 (in Italian)

- Italian Ministry for Cultural Heritage and Activities (2011) Guidelines for Evaluation and Mitigation of Seismic Risk to Cultural Heritage. Gangemi, Rome

- Lagomarsino S (2012) Damage assessment of churches after L'Aquila earthquake (2009). B Earthq Eng 10(1):73-92

- Lemos JV (2007) Discrete element modeling of masonry structures. Int J Archit Herit 1(2):190-213

- Lourenço PB, Mendes N, Ramos LF, Oliveira DV (2011) Analysis of Masonry Structures Without Box Behaviour. Int J Archit Herit 5:369-382

- Magi J (2009) Seismic Vulnerability of Historical Structure Case study: San Marco church in the sequence of 2009 Abruzzo earthquake. Dissertation, University of Padova

- Modena C, Valluzzi MR, Zenere M (2009) c-Sisma 3.0 PRO Procedura automatica per il calcolo e la verifica di meccanismi di pareti in muratura. User manual (in Italian). University of Padova, Padova

- Modena C, Casarin F, da Porto F, Munari M (2010) L'Aquila 6th April 2009 earthquake: emergency and post- emergency activities on cultural heritage buildings. Earthquake Engineering in Europe, 17. Springer, The Netherlands, pp 495-521

- Modena C, Valluzzi MR, da Porto F, Casarin F (2011) Structural Aspects of The Conservation of Historic Masonry Constructions in Seismic Areas: Remedial Measures and Emergency Actions. Int J Archit Herit 5:539-558

- NIKER - New Integrated Knowledge based approaches to the protection cultural heritage from Earthquake induced Risk. NIKER Catalogue. http://www.niker.eu Accessed 27 June 2013

- Pelà L, Aprile A, Benedetti A (2009) Seismic assessment of masonry arch bridges. Eng Struct; 31(8):1777-88

- Pelà L, Cervera M, Roca P (2013a) An orthotropic damage model for the analysis of masonry structures. Constr Build Mater 41:957-967

- Pelà L, Benedetti A, Aprile A, Mangoni E (2013b) Seismic assessment of the Milano Centrale railway station. Int J Archit Herit 7:609-627

- Pelà L. Aprile A. Benedetti, (2013c) Comparison of seismic assessment procedures for masonry arch bridges, Constr Build Mater 38:381-394

- Roca P, Cervera M, Gariup G Pelà L (2010) Structural Analysis of Masonry Historical Constructions. Classical and Advanced Approaches. Arc Comput Methods E 17:299325

- Roca P, Cervera M, Pelà L, Clemente R, Chiumenti M, (2012) Viscoelasticity and damage model for creep behaviour of historical masonry structures. The Open Civ Eng J 6:188-199

- Roca P, Cervera M, Pelà L, Clemente R, Chiumenti M (2013) Continuum FE models for the analysis of Mallorca Cathedral. Eng Struct 46:653-670

- Silva B, Magi J, Casarin F, Modena C, Condoleo P, Cardani G, Binda L (2010) Assessment of the San Marco church structural behaviour in sequence of the April 2009 earthquake in Abruzzo (Italy). $8^{\text {th }}$ International Symposium on the Conservation of Monuments in the Mediterranean Basin. Patras, Greece

- Silva B, Magi J, Casarin F, Modena C, Valluzzi MR, Binda L, Condoleo P (2011) Chiesa di San Marco all'Aquila. Valutazione preliminare dei danni (in Italian). L'università e la ricerca per l'Abruzzo - II patrimonio culturale dopo il terremoto del 6 aprile 2009. Textus, L'Aquila, pp 78-85 
- TNO Diana (2005) DIANA-finite element analysis. The Netherlands

- Zografou A (2010) Structural Modeling of masonry structures severely damaged by earthquake - Case study of St. Marco's church in L'Aquila. Dissertation, University of Padova 


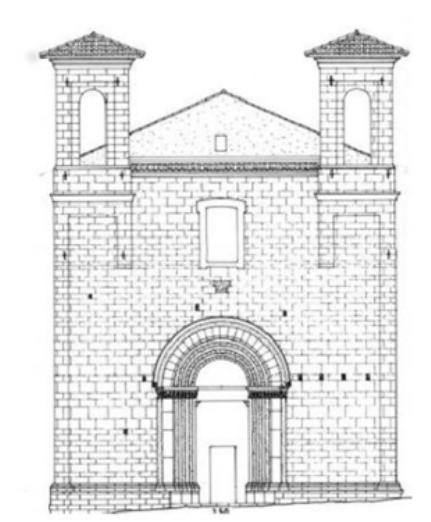

(a)

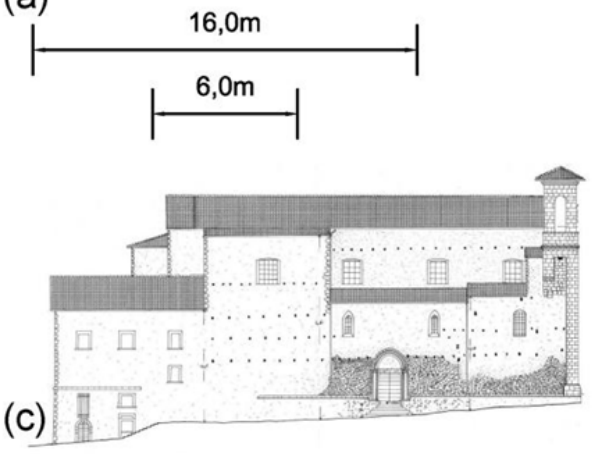

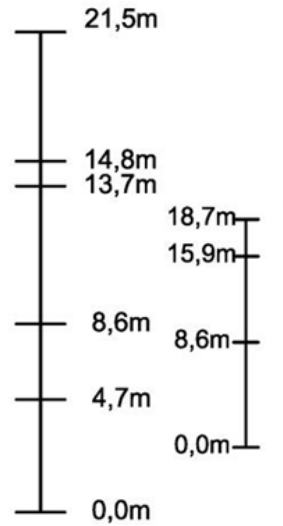

(b)

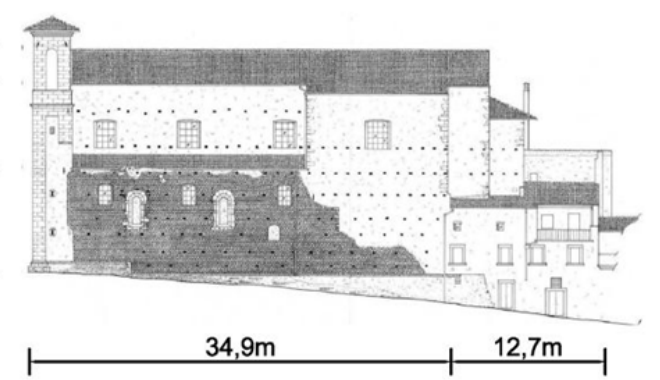

(d)

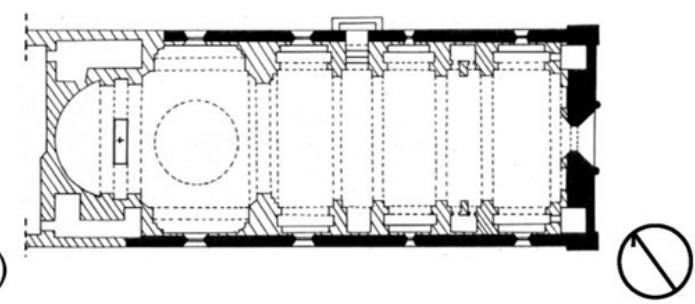

Figure 1 - San Marco church: (a-b-c) façade, north and south side, (d) plan.

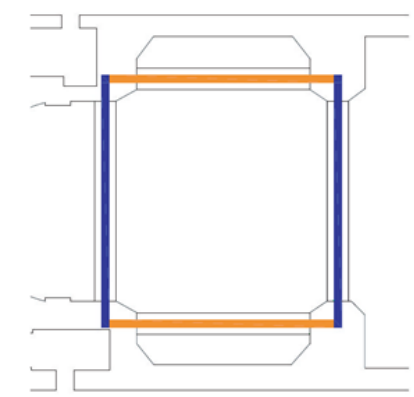

(a) (b)

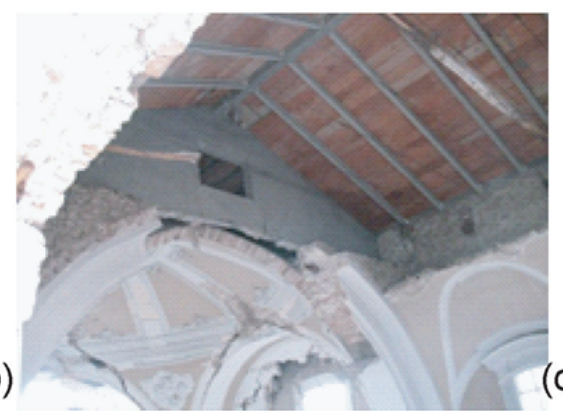

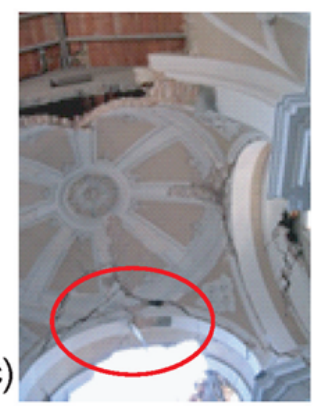

Figure 2 - Past interventions visible after the earthquake: (a) location of RC beams and tympanums, (b) RC tympanum over the transept and new roof and (c) CFRP strips installed on the intrados of arches. 

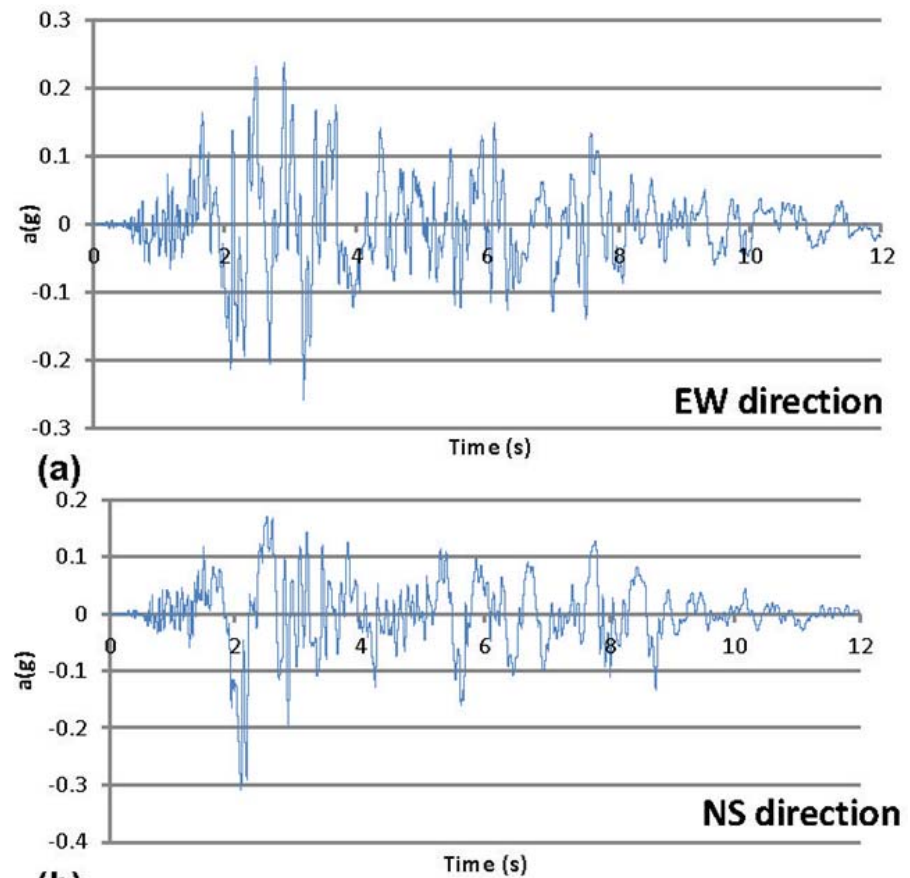

(b)

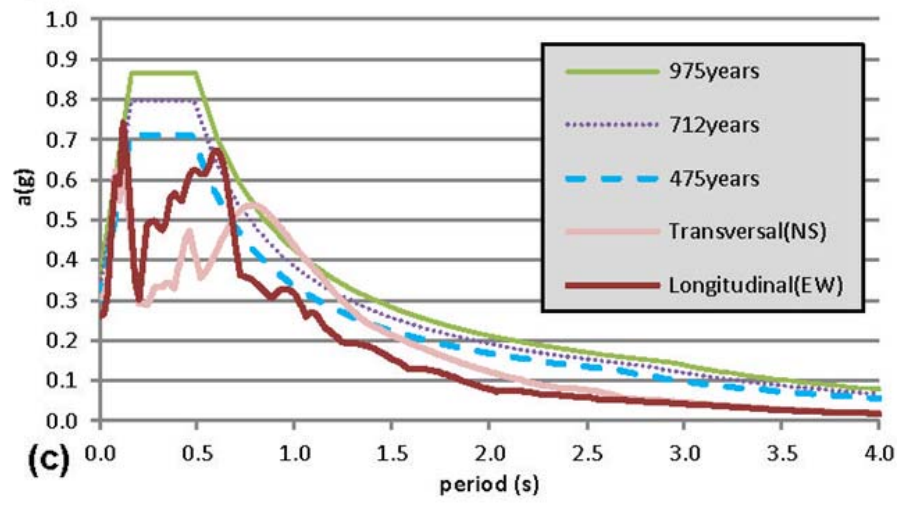

Figure 3 - Accelerograms of L'Aquila main shock in the EW direction (a) and NS direction (b), comparison of corresponding spectra with those provided by Italian standards for the city of L'Aquila for different return periods (c). 


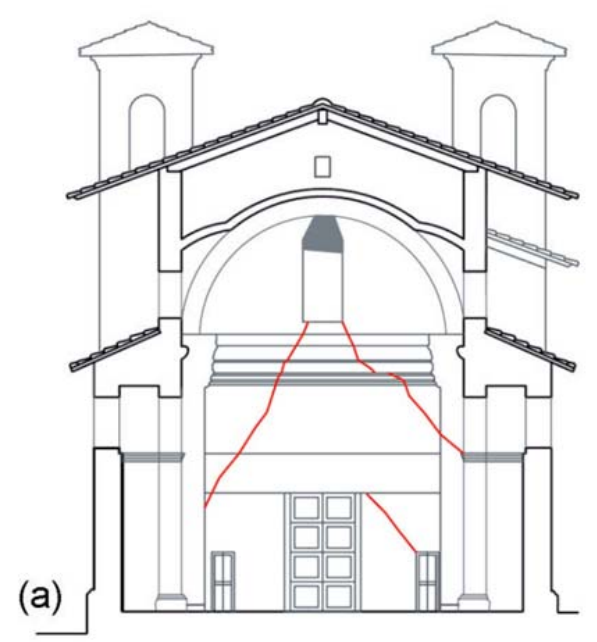

(b)

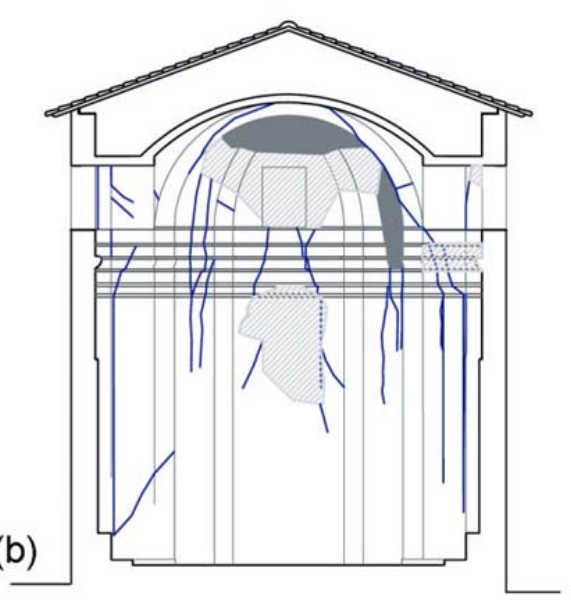

(c)

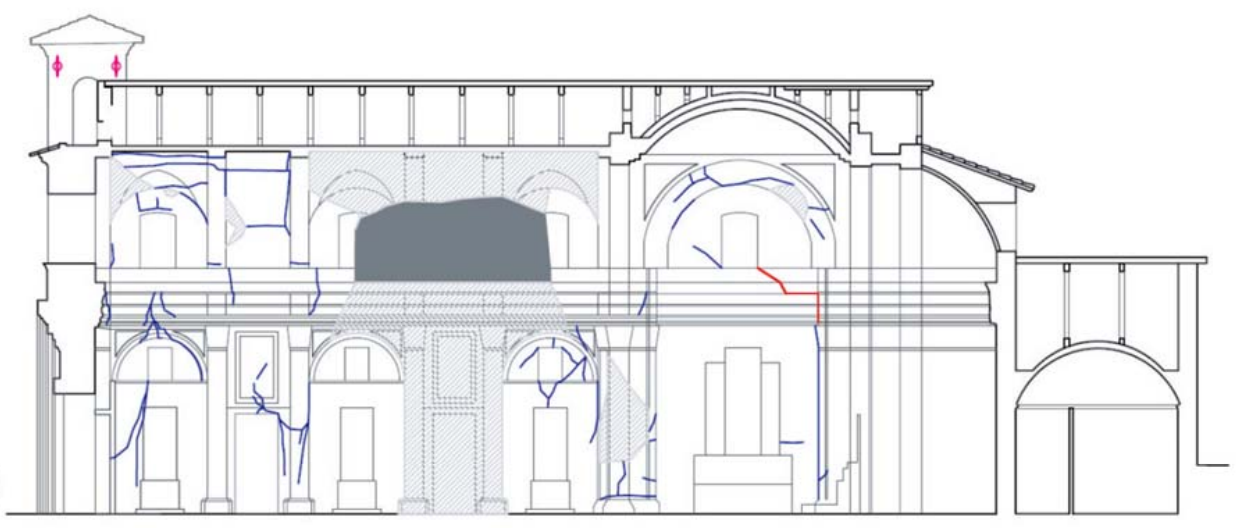

(d)

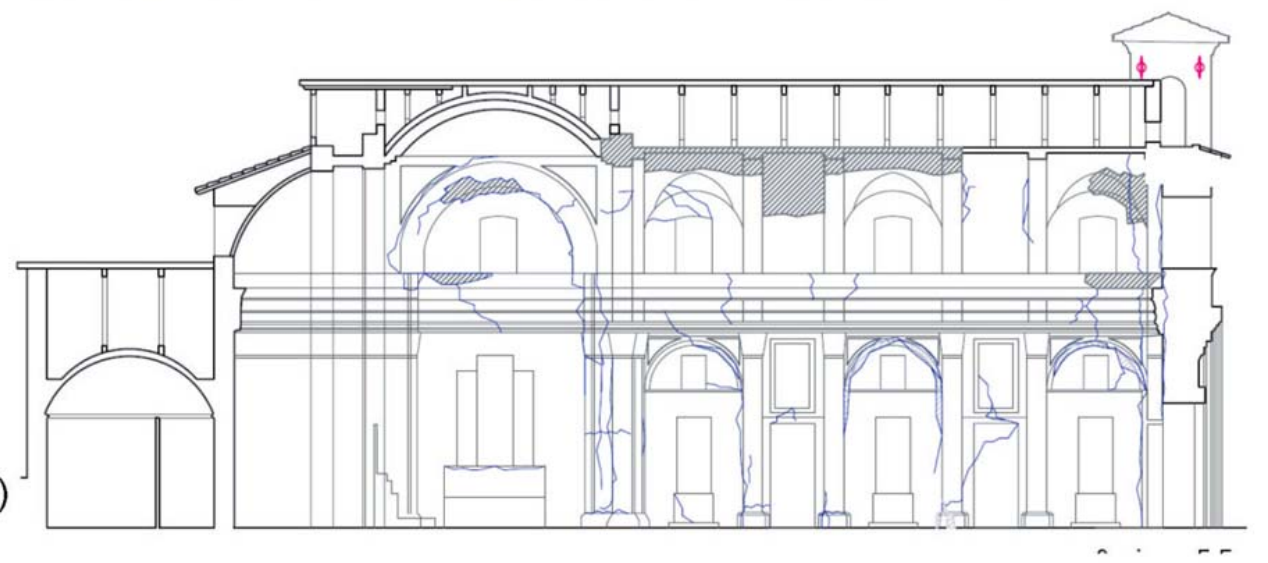

(e)

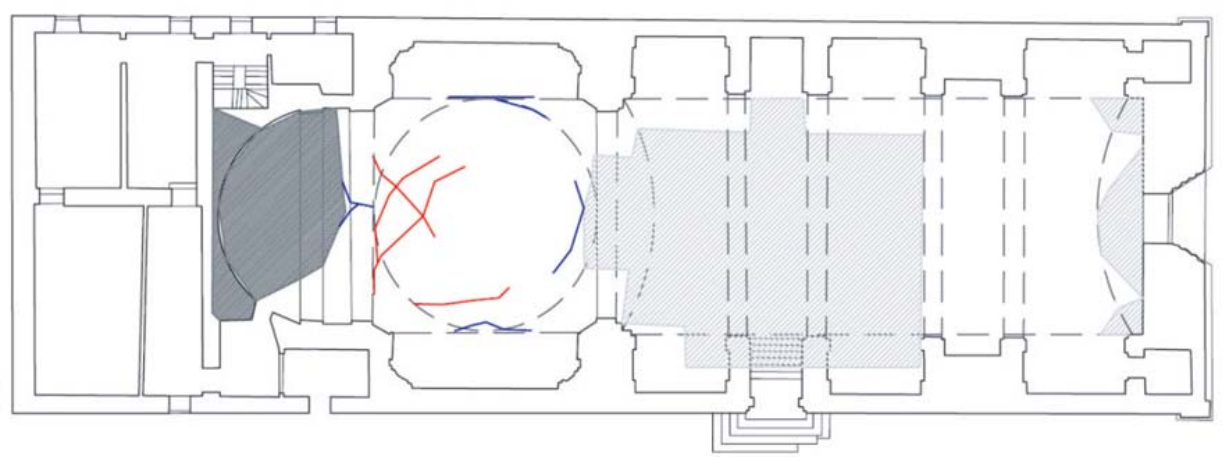

Figure 4 - Maps of crack patterns observed after the earthquake: (a) façade, (b) apse, (c-d) nave and chapels and (e) top view. 

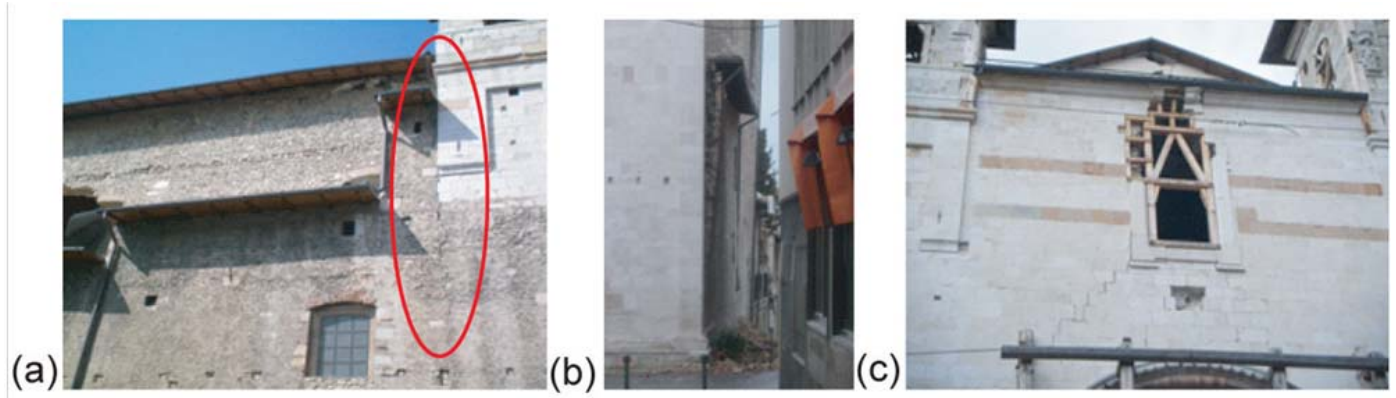

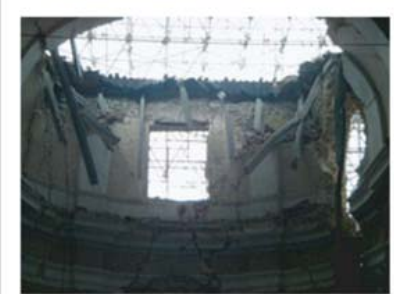

(d)

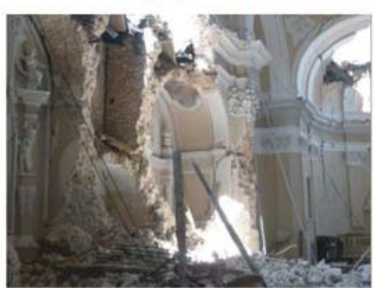

(e)

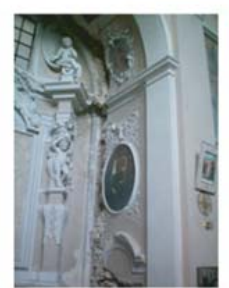

(f)

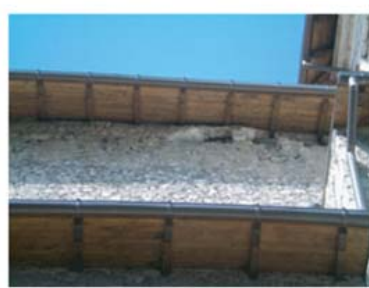

(g)

Figure 5 - Some mechanisms observed after the earthquake: (a) overturning of façade and (b) lateral chapel walls, (c) shear mechanism in the façade, (d) collapse of the semi-dome and the roof in the apse, (e) collapse of the lateral chapel and the wall above, $(f)$ disconnection between the chapel wall and external wall and $(g)$ damage under the roof in the south nave wall. 


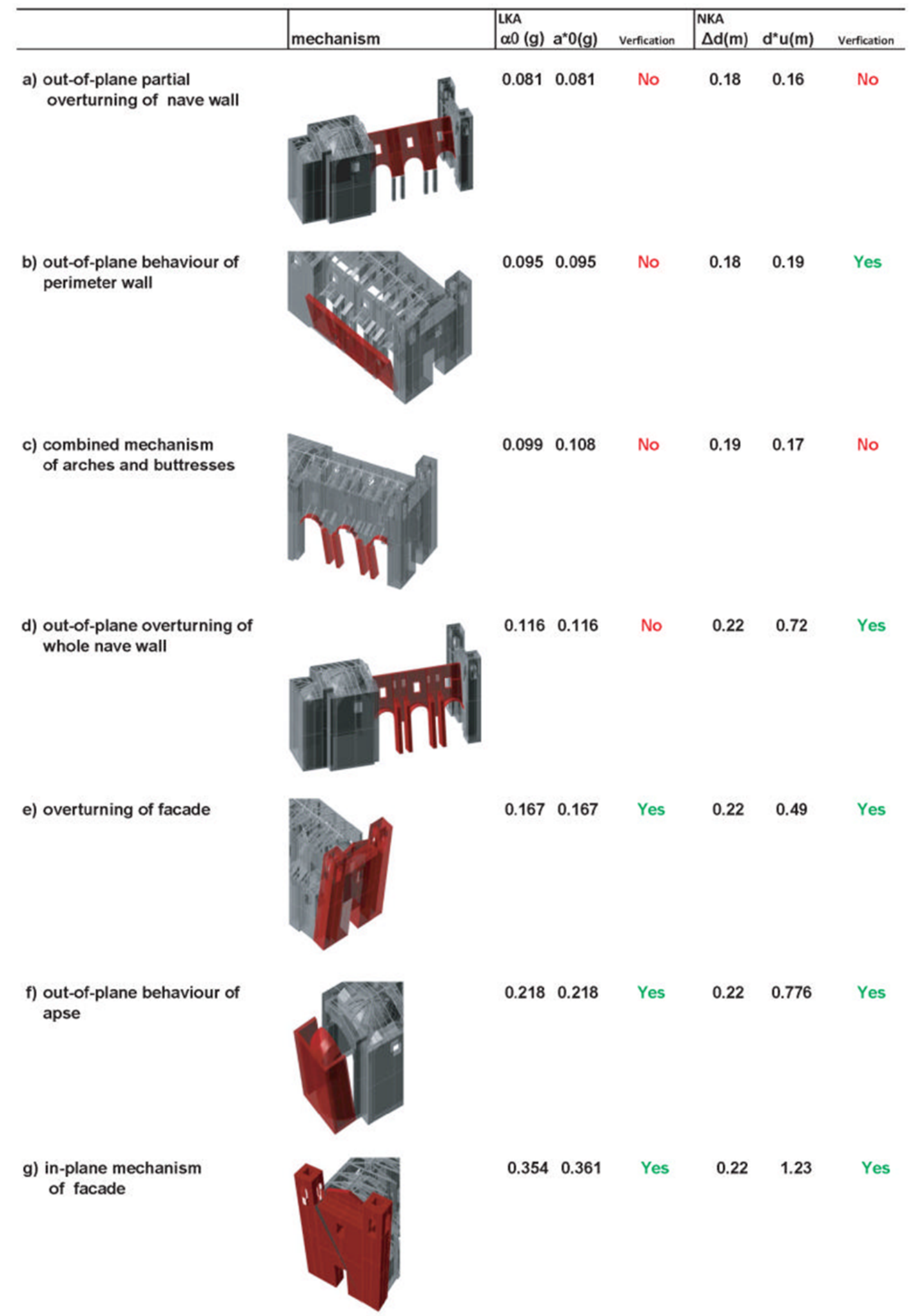

Figure 6 - Collapse mechanisms and corresponding coefficients obtained by limit analysis. 
(a)
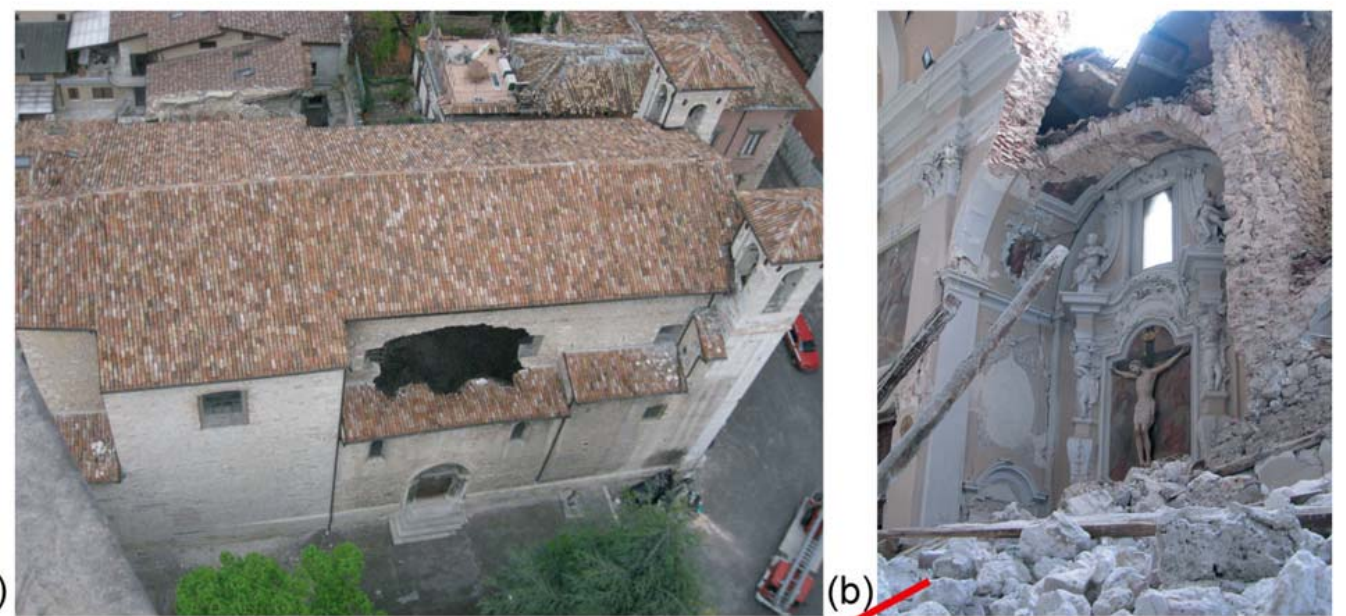

(c)

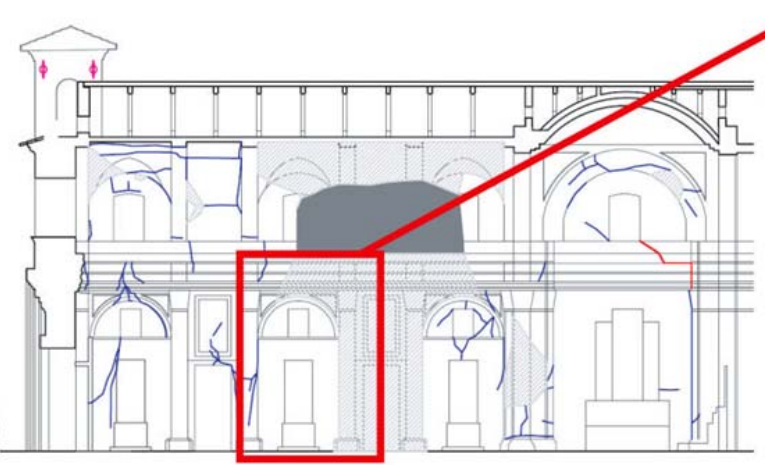

(d)

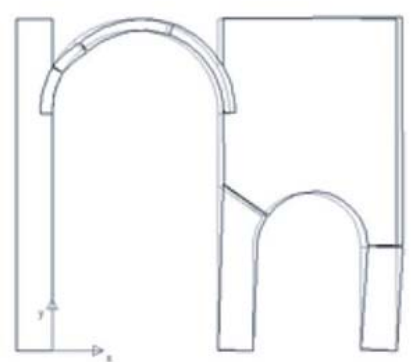

Figure 7 - Collapse of the chapels and upper part of the south nave wall (De Conti 2013): (a) outside and (b) inside views, (c) identification of the macroelement and (d) kinematic analysis of the mechanism.

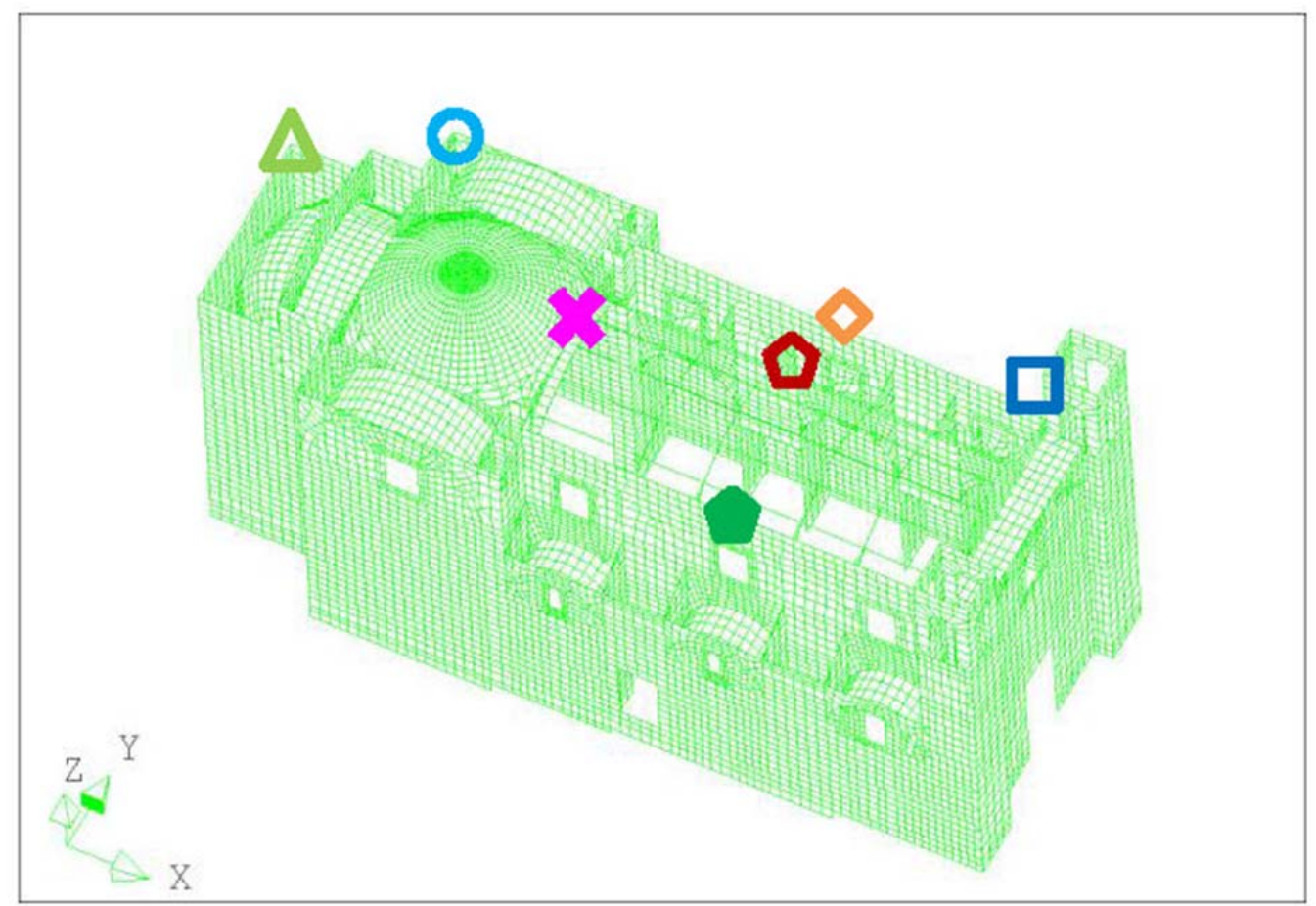

Figure 8 - Global FE model of San Marco church and location of control nodes for nonlinear seismic analyses. 


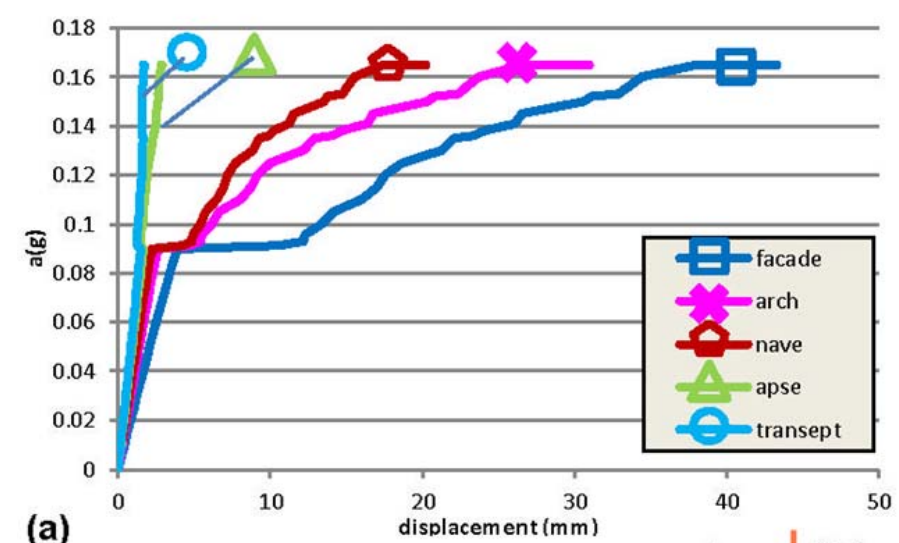

(a)

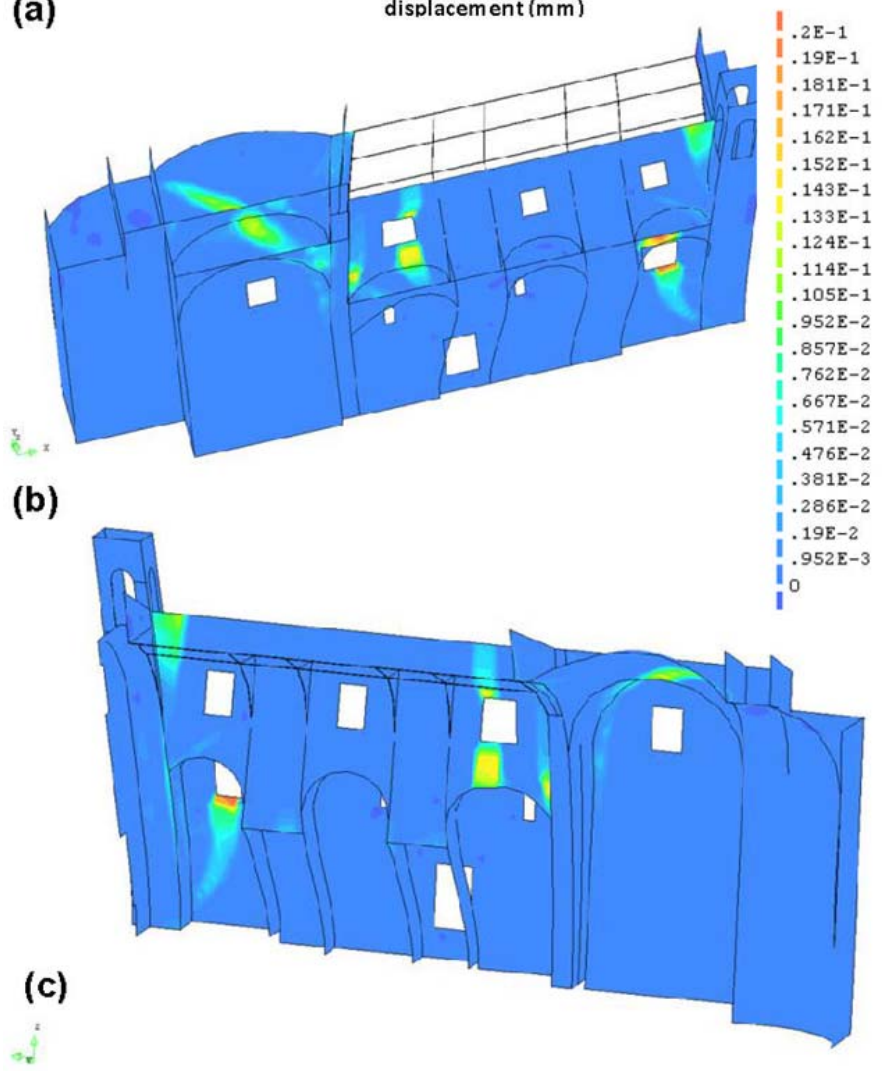

Figure 9 - Pushover analysis in the positive longitudinal direction (+X): (a) capacity curves at different control nodes and $(b-c)$ contour of principal tensile strain at the ultimate state.

(a)

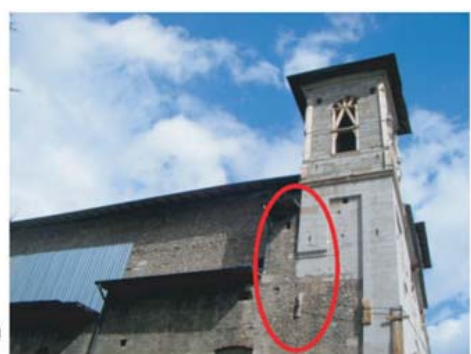

(b)

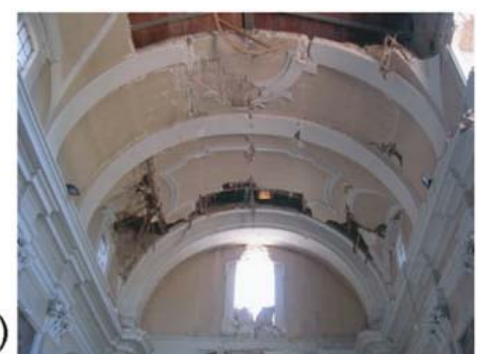

(c)

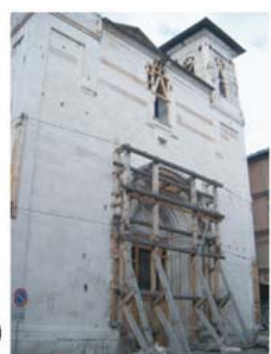

Figure 10 - Real collapse mechanism detected by $+X$ direction pushover analysis: (a) overturning of the façade seen from the exterior and (b) from the interior, (c) post-earthquake urgent intervention by ties and timber propping. 

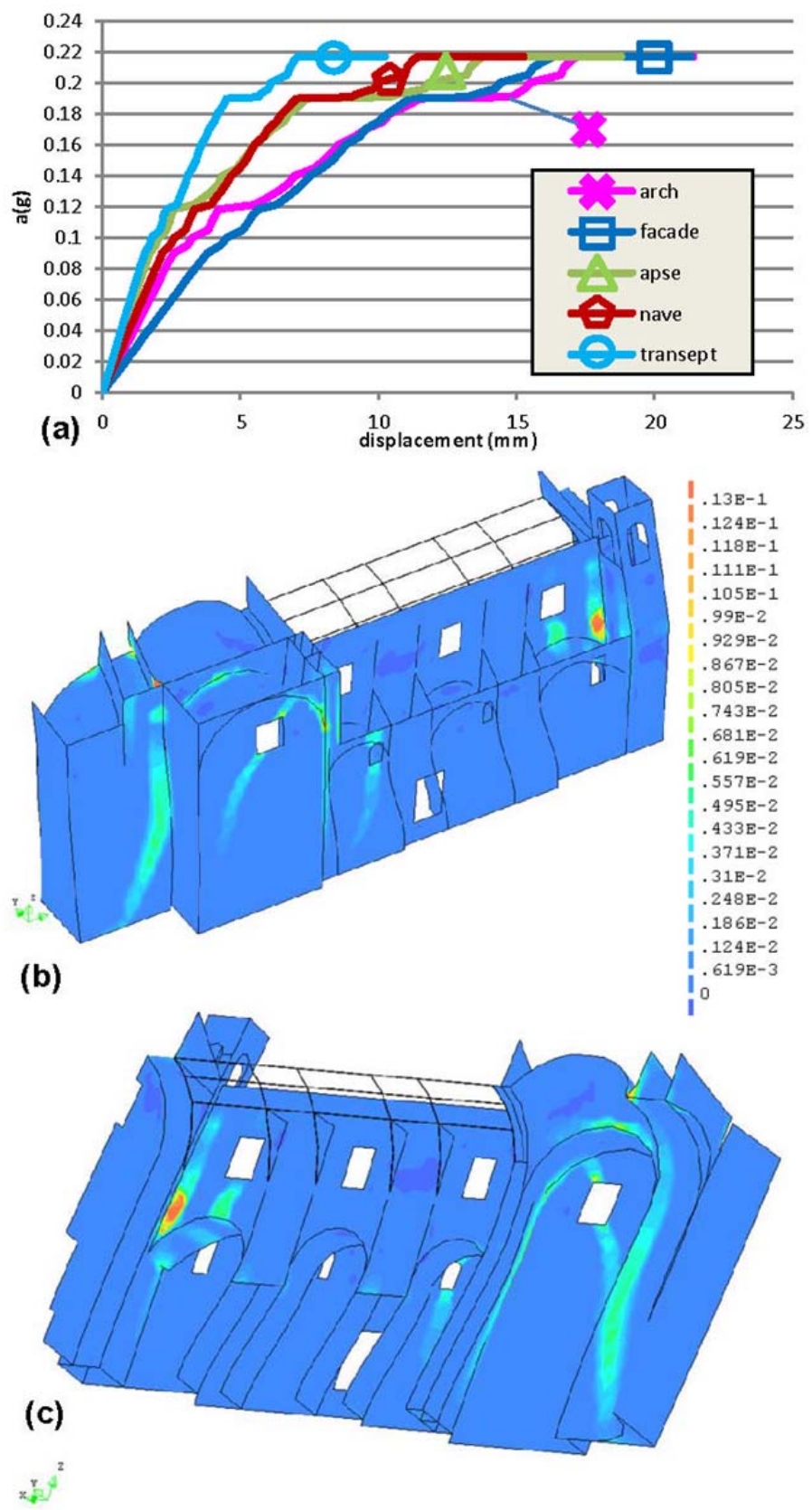

Figure 11 - Pushover analysis in the negative longitudinal direction (-X): (a) capacity curves at different control nodes and $(b-c)$ contour of principal tensile strain at the ultimate state. 
(a)

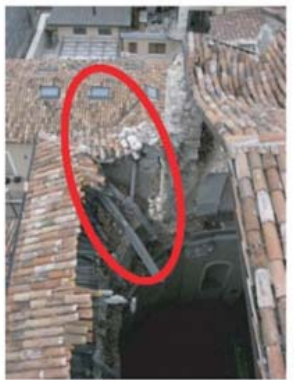

(b)

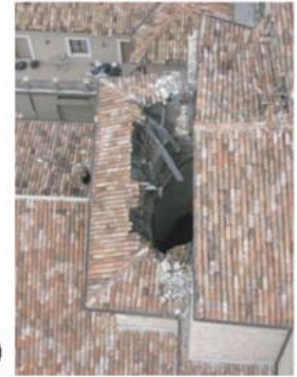

(c)

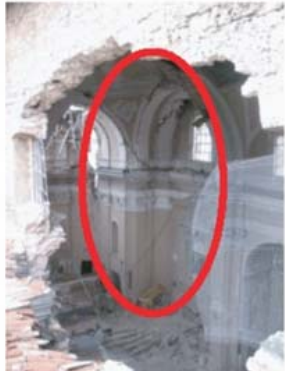

(d)

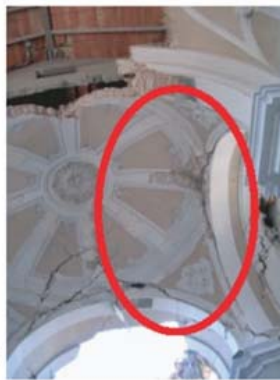

Figure 12 - Collapse mechanisms detected by -X direction pushover analysis: (a-b) out-of-plane overturning of the apse and (c-d) separation of the transept wall from the arch sustaining the dome. 

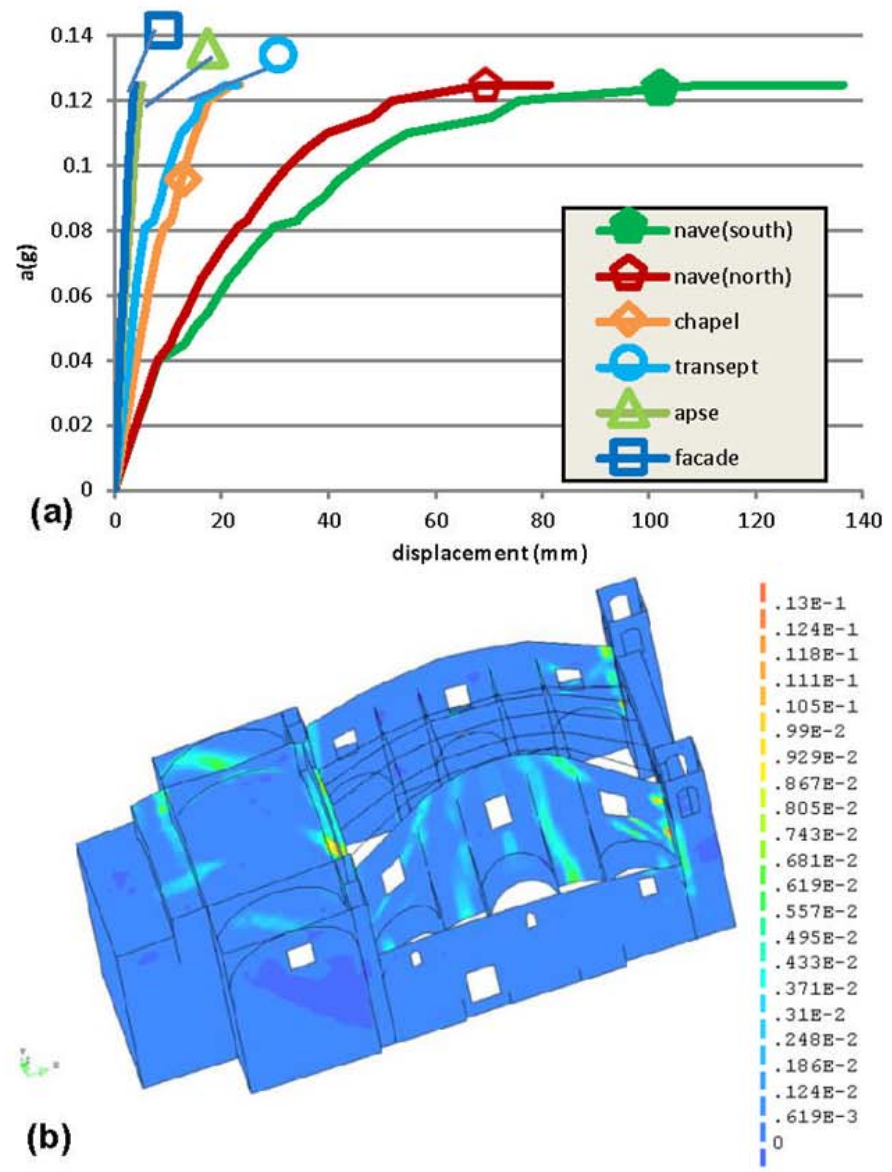

(b) $0^{.619 \mathrm{E}-3}$

(c)

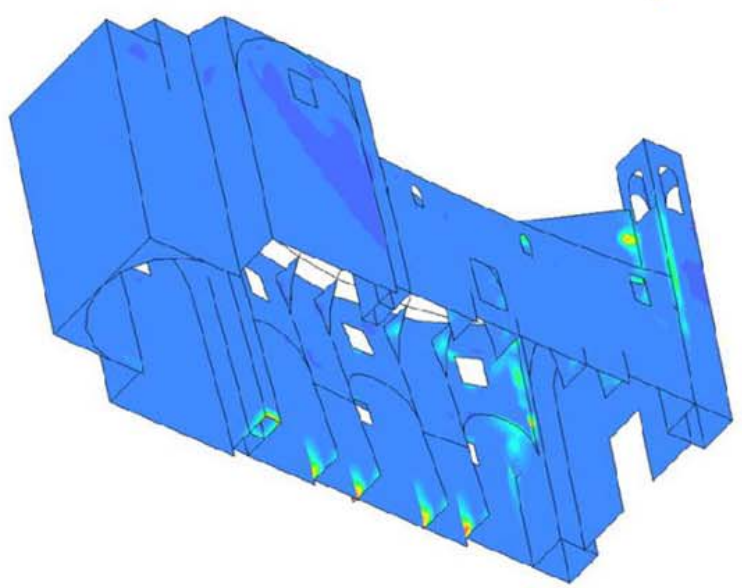

Figure 13 - Pushover analysis in the transversal direction $(\mathrm{Y})$ : (a) capacity curves at different control nodes and $(b-c)$ contour of principal tensile strain at the ultimate state. 
(a)

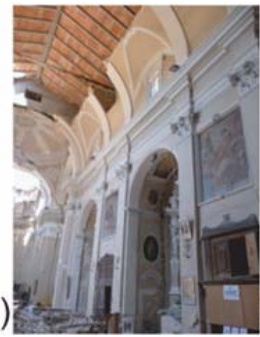

(b)

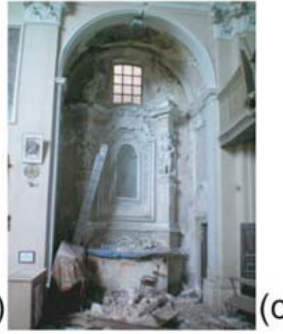

(c)

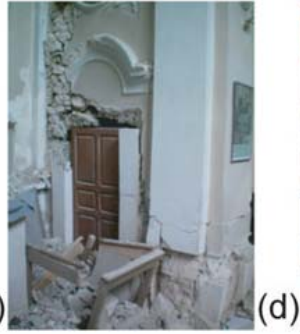

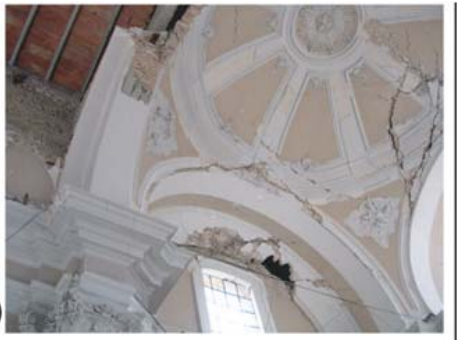

Figure 14 - Collapse mechanisms detected by $Y$ direction pushover analysis: (a) arches in the nave, (b-c) walls and buttresses in lateral chapels, d) transept arches. 

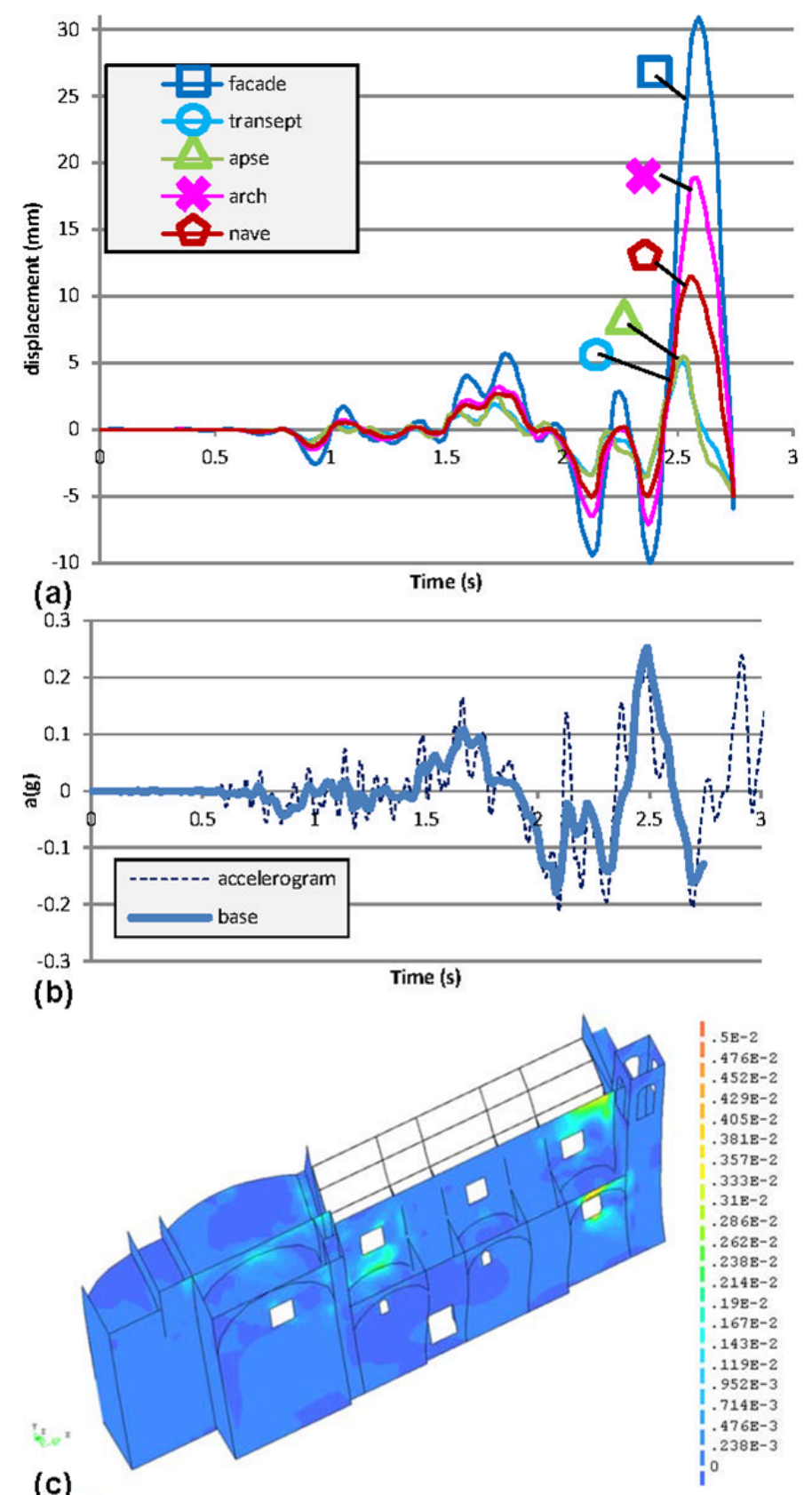

(c)

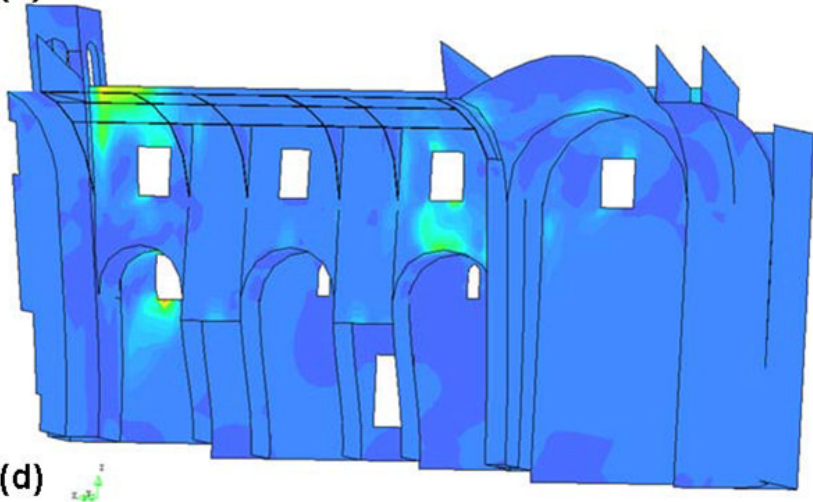

Figure 15 - NDA in the longitudinal direction (X): (a) time-history of displacements at different control nodes, (b) comparison accelerogram vs. acceleration at the base of the structure and (c-d) contour of principal tensile strain at $2.6 \mathrm{sec}$. 


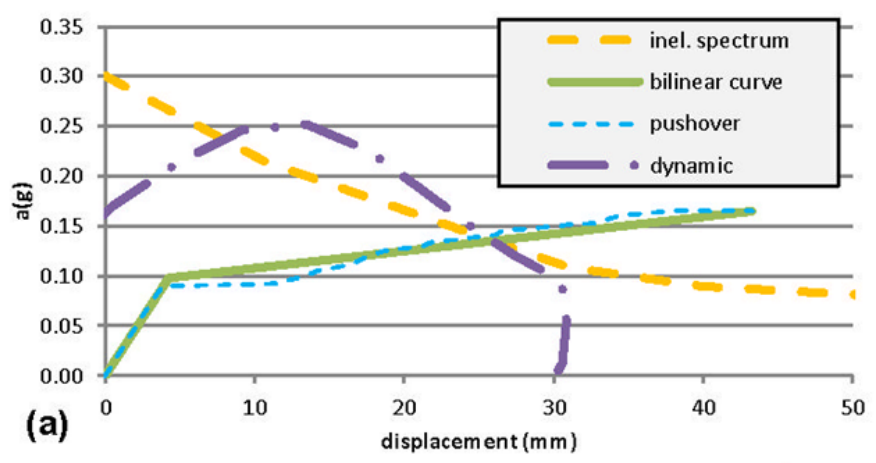

(a)

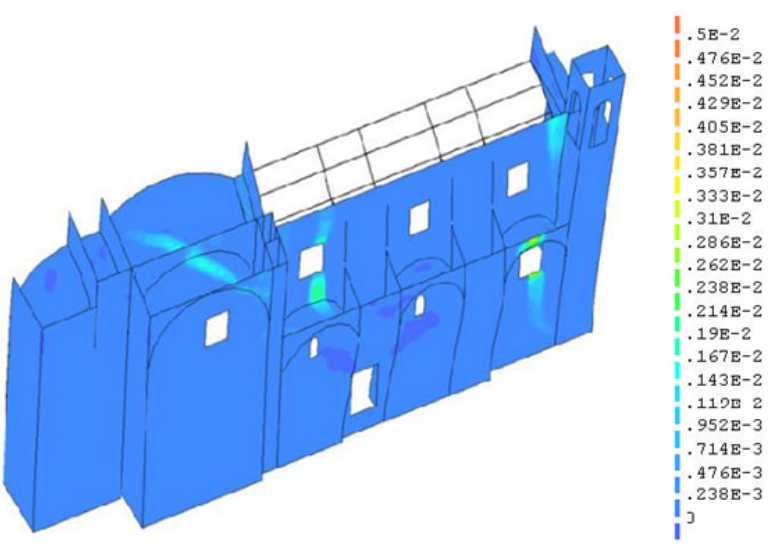

(b)

Figure 16 - Comparison between NDA and N2 method, longitudinal direction (X), top of the façade control node: (a) NDA acceleration-displacement envelope compared with the capacity curve and (b) contour of principal tensile strains at the performance point of pushover analysis. 


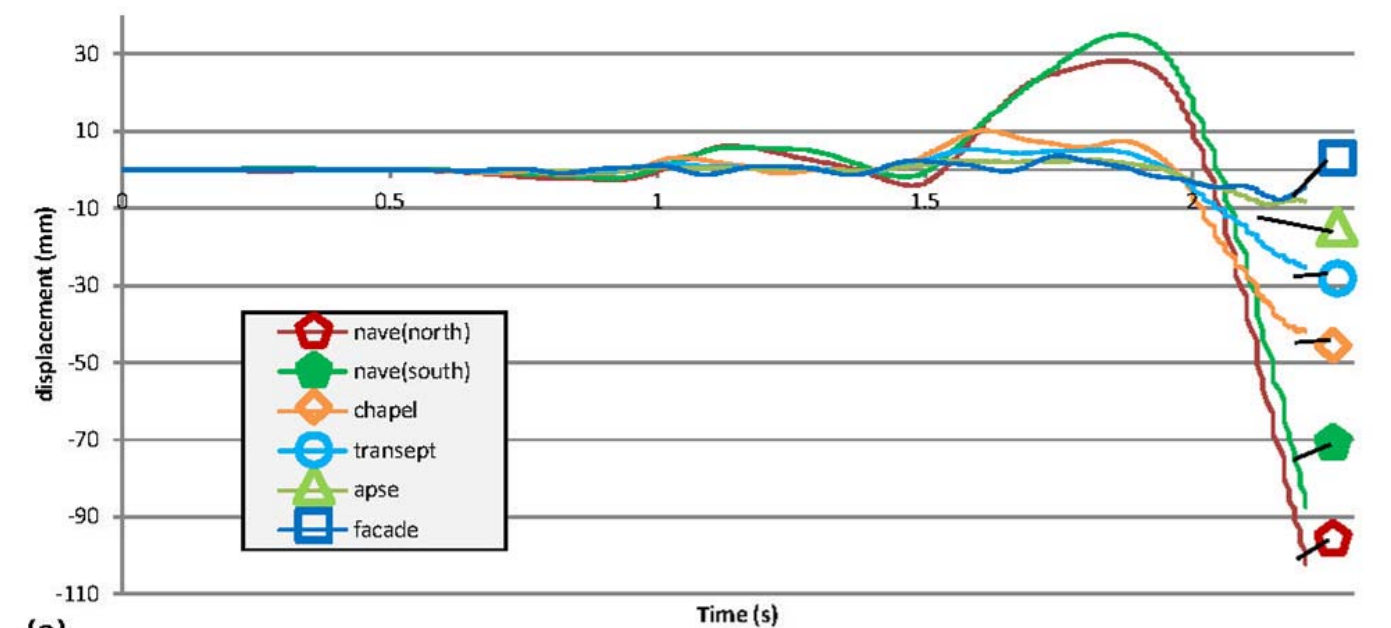

(a)
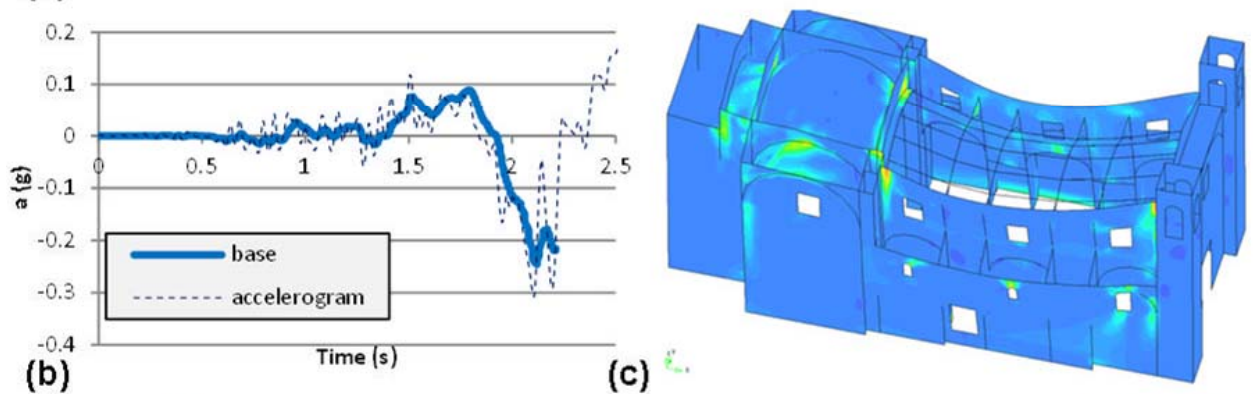

\begin{tabular}{|}
$.5 \mathrm{~B}-2$ \\
$.476 \mathrm{E}-2$ \\
$.452 \mathrm{E}-2$ \\
$.429 \mathrm{E}-2$ \\
$.405 \mathrm{E}-2$ \\
$.381 \mathrm{E}-2$ \\
$.357 \mathrm{E}-2$ \\
$.333 \mathrm{E}-2$ \\
$.31 \mathrm{~B}-2$ \\
$.286 \mathrm{E}-2$ \\
$.262 \mathrm{E}-2$ \\
$.238 \mathrm{~B}-2$ \\
$.214 \mathrm{E}-2$ \\
$.19 \mathrm{~B}-2$
\end{tabular}

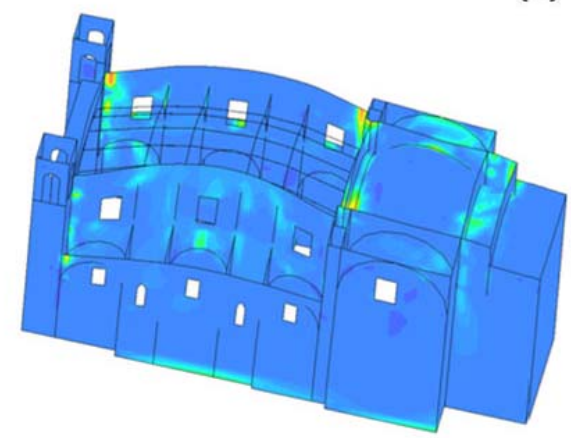

(e)

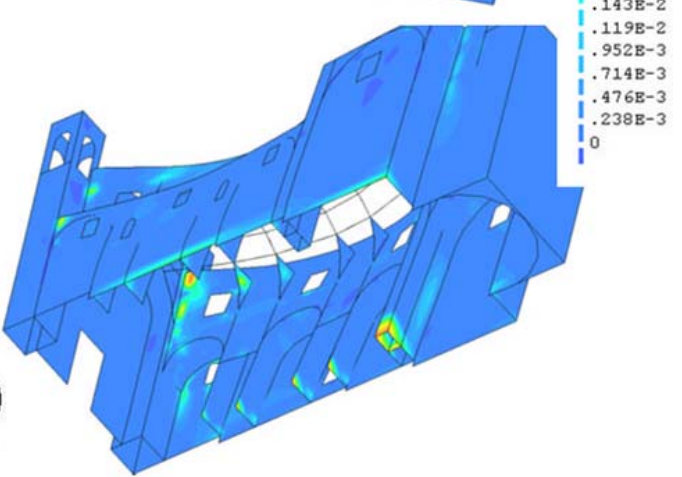

Figure 17 - NDA in the transversal direction $(\mathrm{Y})$ : (a) time-history of displacements at different control nodes (b) comparison accelerogram vs. acceleration at the base of the structure and (c-e) contour of principal tensile strain at $2.21 \mathrm{sec}$. 

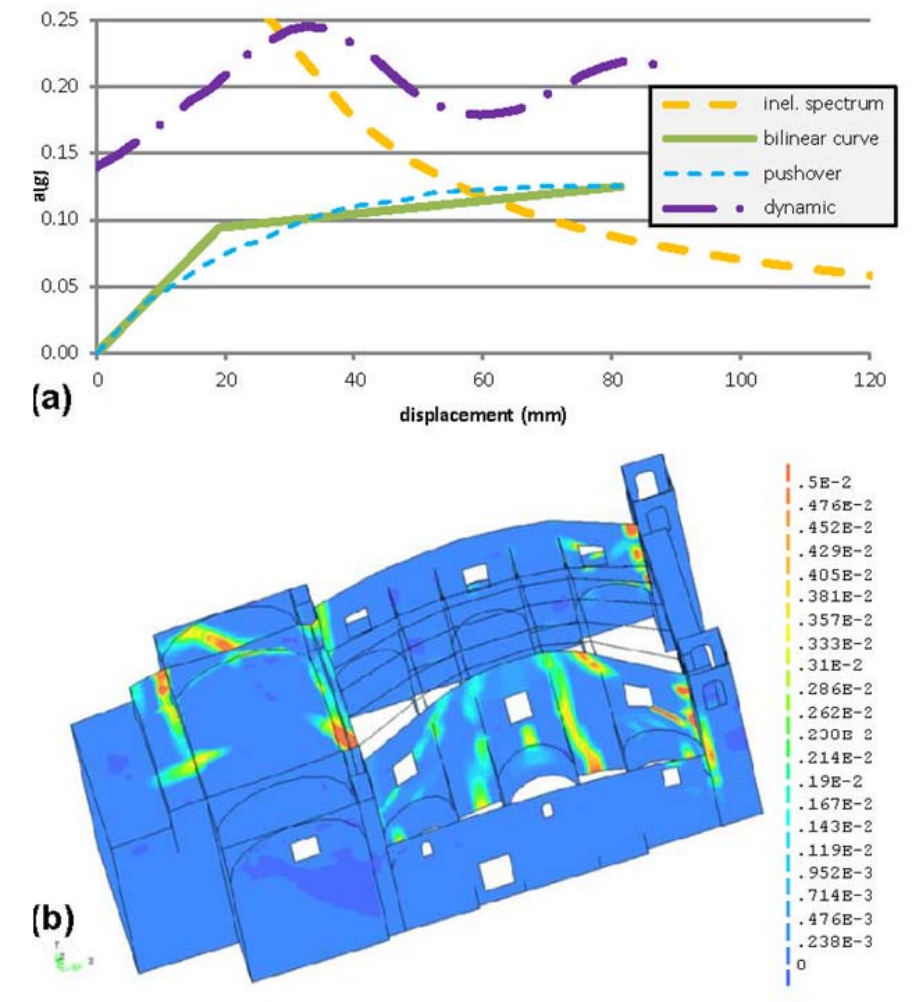

Figure 18 - Comparison between NDA and N2 method, transversal direction (Y), top of the nave wall control node: (a) NDA acceleration-displacement envelope compared with the capacity curve and (b-c) contour of principal tensile strain at the performance point of pushover analysis. 


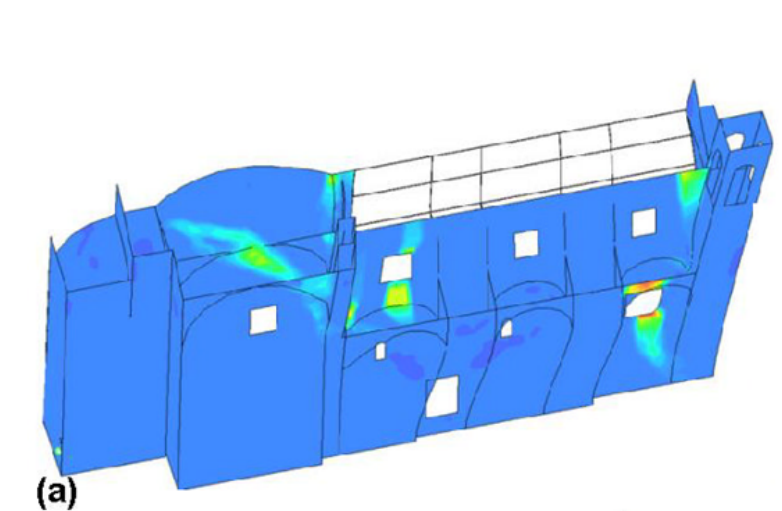
$.2 \mathrm{E}-1$
$.19 \mathrm{~F}-1$ $.181 \mathrm{E}-1$ $.171 E-1$ $.162 \mathrm{E}-1$ $.143 \mathrm{E}-1$ $.133 \mathrm{E}-1$ $114 \mathrm{E}-1$ .105E-1 (057E-2 $381 \mathrm{E}-2$
$.86 \mathrm{E}-2$ $19 \mathrm{E}-2$

(a) .95<E-

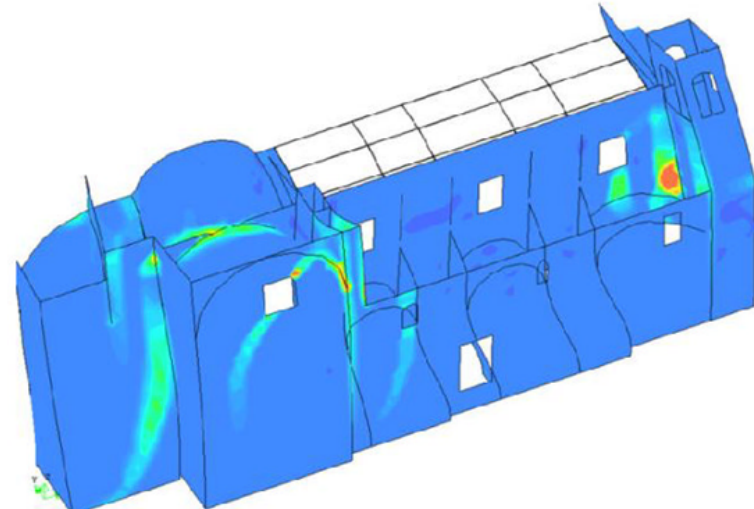

(b)

I. $13 \mathrm{E}-1$

.

$.99 \mathrm{k}-2$

. $36^{7} \mathrm{~B}-2$

.

1.74

$.619 \mathrm{~B}-2$

. $55^{7} \mathrm{~B}-2$

$.495 \mathrm{R}-7$

$.433 \mathrm{~B}-2$

$.31 \mathrm{k}-2$

2408-2

$.6198-3$

i.

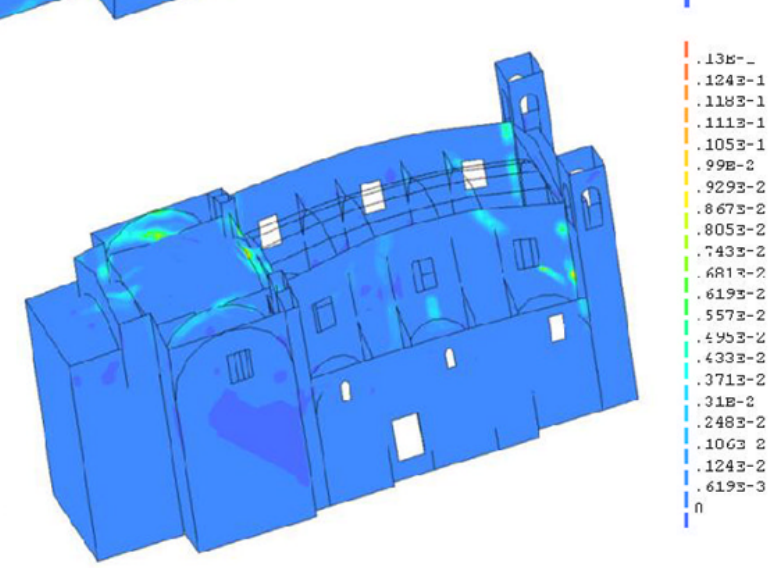

(c)

Figure 19 - Pushover analysis of the model of the church before the interventions with RC members of 1970: contour of the principal tensile strain at the ultimate state for (a) positive longitudinal direction (+X), (b) negative longitudinal direction $(-\mathrm{X})$ and $(\mathrm{c})$ transversal direction $(\mathrm{Y})$. 


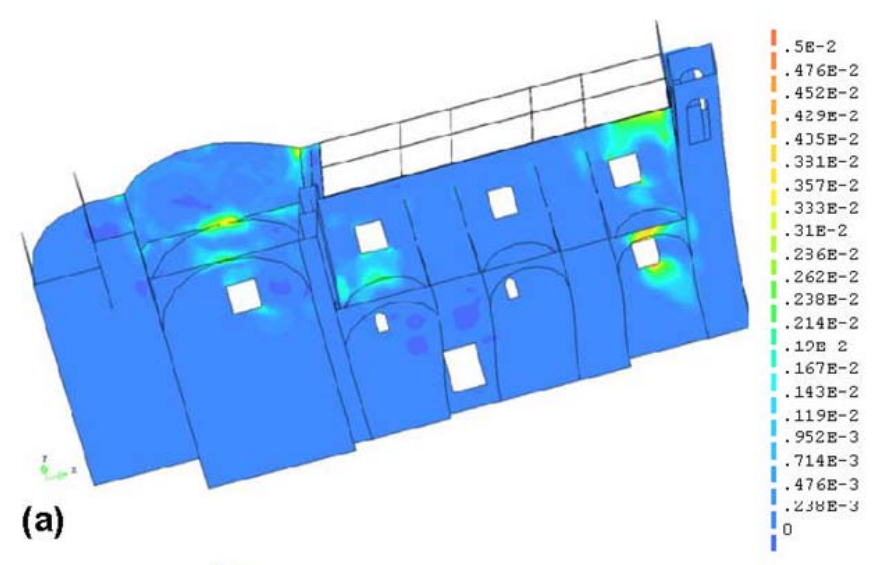

(b)

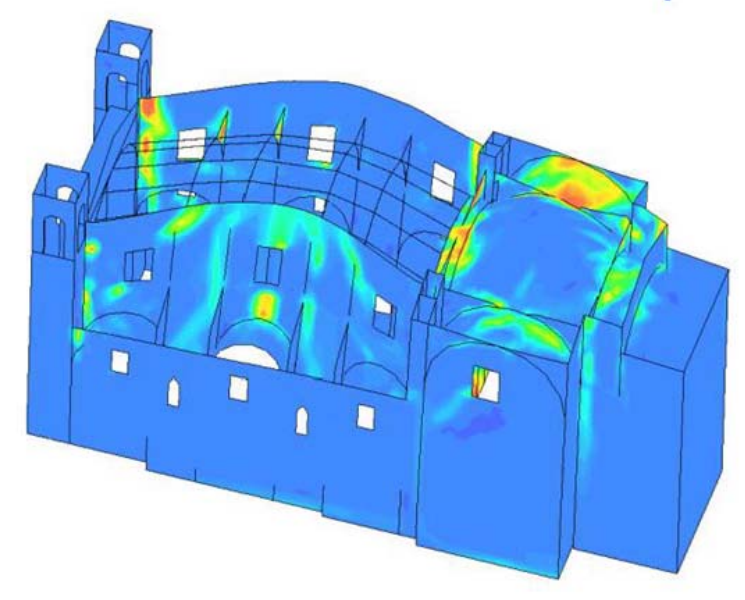

Figure 20 - NDA of the model of the church before the interventions with RC members of 1970. Contour of the principal tensile strain at the maximum displacement: (a) longitudinal direction ( 2.6 seconds) and (b) transversal direction (2.37 seconds).

Table 1 - Mechanical properties for FEM analysis.

\begin{tabular}{lcccc}
\hline & stone masonry & brick masonry & $\begin{array}{c}\text { timber } \\
\text { reinforced } \\
\text { concrete }\end{array}$ \\
\hline Density $\left(\mathrm{kg} / \mathrm{m}^{3}\right.$ ) & 2000 & 1800 & 650 & 2400 \\
Compressive strength (MPa) & 4 & 4 & - & 15 \\
Young's modulus (MPa) & 2000 & 2000 & 11000 & 20000 \\
Tensile strength (MPa) & 0.2 & 0.2 & - & 1 \\
Poisson ratio (-) & 0.2 & 0.2 & 0.2 & 0.2 \\
Fracture energy (N/m) & 50 & 50 & - & 100 \\
\hline
\end{tabular}

